\title{
Characterization and Localization of Cannabinoid Receptors in Rat Brain: A Quantitative in vitro Autoradiographic Study
}

\author{
Miles Herkenham, ${ }^{1}$ Allison B. Lynn, ${ }^{1}$ M. Ross Johnson, ${ }^{2}$ Lawrence S. Melvin, ${ }^{3}$ Brian R. de Costa, ${ }^{4}$ and Kenner \\ C. Rice $^{2}$ \\ 'Section on Functional Neuroanatomy, National Institute of Mental Health, Bethesda, Maryland 20892, ${ }^{2}$ Glaxo \\ Incorporated, Research Triangle Park, North Carolina 27709, ${ }^{3}$ Pfizer Incorporated, Central Research, Groton, Connecticut \\ 06340, and 4 Laboratory of Medicinal Chemistry, National Institute of Diabetes and Digestive and Kidney Diseases, \\ Bethesda, Maryland 20892
}

\begin{abstract}
A potent, synthetic cannabinoid was radiolabeled and used to characterize and precisely localize cannabinoid receptors in slide-mounted sections of rat brain and pituitary. Assay conditions for ${ }^{3} \mathrm{H}-\mathrm{CP} 55,940$ binding in Tris- $\mathrm{HCl}$ buffer with $5 \%$ BSA were optimized, association and dissociation rate constants determined, and the equilibrium dissociation constant $\left(K_{d}\right)$ calculated ( $21 \mathrm{~nm}$ by liquid scintillation counting, $5.2 \mathrm{~nm}$ by quantitative autoradiography). The results of competition studies, using several synthetic cannabinoids, add to prior data showing enantioselectivity of binding and correlation of in vitro potencies with potencies in biological assays of cannabinoid actions. Inhibition of binding by guanine nucleotides was selective and profound: Nonhydrolyzable analogs of GTP and GDP inhibited binding by $>90 \%$, and GMP and the nonhydrolyzable ATP analog showed no inhibition. Autoradiography showed great heterogeneity of binding in patterns of labeling that closely conform to cytoarchitectural and functional domains. Very dense ${ }^{3} \mathrm{H}-\mathrm{CP} 55,940$ binding is localized to the basal ganglia (lateral caudateputamen, globus pallidus, entopeduncular nucleus, substantia nigra pars reticulata), cerebellar molecular layer, innermost layers of the olfactory bulb, and portions of the hippocampal formation (CA3 and dentate gyrus molecular layer). Moderately dense binding is found throughout the remaining forebrain. Sparse binding characterizes the brain stem and spinal cord. Densitometry confirmed the quantitative heterogeneity of cannabinoid receptors $\left(10 \mathrm{~nm}{ }^{3} \mathrm{H}-\right.$ CP55,940 binding ranged in density from $6.3 \mathrm{pmol} / \mathrm{mg}$ protein in the substantia nigra pars reticulata to $0.15 \mathrm{pmol} / \mathrm{mg}$ protein in the anterior lobe of the pituitary). The results suggest that the presently characterized cannabinoid receptor mediates physiological and behavioral effects of natural and synthetic cannabinoids, because it is strongly coupled to guanine nucleotide regulatory proteins and is discretely localized to cortical, basal ganglia, and cerebellar structures involved with cognition and movement.
\end{abstract}

Marijuana (Cannabis sativa) is one of the oldest and most widely used drugs in the world, with a history of use dating back over 4000 years (Harris et al., 1977; Abel, 1980; Mechoulam, 1986).

\footnotetext{
Received July 12, 1990; revised Oct. 18, 1990; accepted Oct. 24, 1990.

Correspondence should be addressed to Miles Herkenham, Ph.D., Section on Functional Neuroanatomy, National Institute of Mental Health, Building 36, Room 2D15, Bethesda, MD 20892.

Copyright (c) 1991 Society for Neuroscience $0270-6474 / 91 / 110563-21 \$ 03.00 / 0$
}

The main psychoactive constituent of the marijuana plant, $\Delta^{y}$ tetrahydrocannabinol $\left(\Delta^{9}-\mathrm{THC}\right)$, was identified about 20 years ago (Gaoni and Mechoulam, 1964; Grunfeld and Edery, 1969; Mechoulam et al., 1970). $\Delta^{9}$-THC, $\Delta^{8}$-THC, their active metabolites, and synthetic cannabinoids produce a unique spectrum of CNS-mediated behavioral, physiological, and cognitive effects (Dewey, 1986; Hollister, 1986). However, until recently, very little was known about the cellular mechanisms through which cannabinoids act.

Without evidence that cannabinoids act through a specific receptor coupled to a functional effector system, researchers were prone to study the effects of cannabinoids on membrane properties, membrane-bound enzymes, eicosanoid production, metabolism, and other neurotransmitter systems in vitro (Hilliard et al., 1985; Martin, 1986; Pertwee, 1988; Reichman et al., 1988). As pointed out before (Howlett et al., 1990), most of the biochemical studies employed concentrations of $\Delta^{9}$-THC that were in excess of physiologically meaningful concentrations that might be found in the brain (for review, see Martin, 1986; Pertwee, 1988). In addition, the criterion of structure-activity relationship was not met - that is, the potencies of various cannabinoids in the in vitro assays did not correlate with their relative potencies in eliciting characteristic behavioral effects (Martin, 1986; Howlett et al., 1990). Particularly damaging to the relevance of these in vitro studies was the absence of enantioselectivity (Howlett et al., 1990).

However, several groups have reported enantioselectivity of THC isomers in various behavioral tests in vivo. Martin's group found that the potencies of $(-)$ and $(+)$ forms of each of the cis and trans isomers of $\Delta^{9}$-THC differ by 10 - to 100 -fold in producing static ataxia in dogs, depressing schedule-controlled responding in monkeys, and in producing hypothermia and inhibiting spontaneous activity in mice (Martin et al., 1981). Hollister et al. (1987) showed cannabinoid enantioselectivity in human studies using indices of the subjective experience, or "high." May's group found enantioselectivity of a series of synthetic cannabinoids in tests of motor depression and analgesia (Wilson and May, 1975; Wilson et al., 1976, 1979).

One of May's compounds, (-)-9-nor-9 $\beta$-hydroxyhexahydrocannabinol $(\beta-\mathrm{HHC})$, was used as a lead compound by Johnson and Melvin (1986) for the synthesis of a rather large series of structurally novel, classical and nonclassical, cannabinoids for studies of their potential use as analgesics (Fig. 1). The synthetic cannabinoids share physicochemical properties with the natural cannabinoids and produce many behavioral and physiological effects characteristic of $\Delta^{9}$-THC, but are 5-1000 times more potent and show high enantioselectivity. 


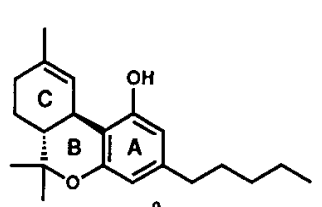

$(-)-\Delta^{9}-$ THC

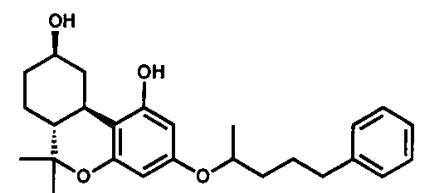

$( \pm)-C P 42,096$

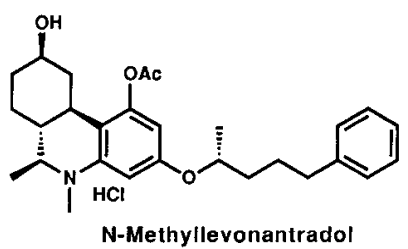

N-Methyllevonantradol

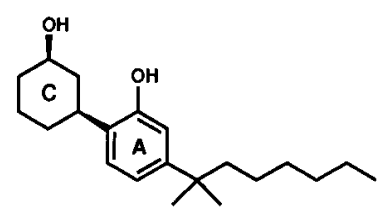

$(-)-C P 47,497$

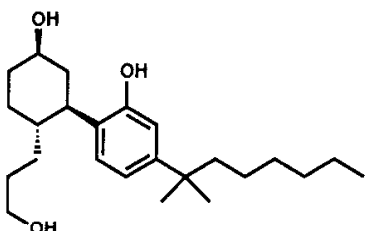

$(-)-C P 55,940$

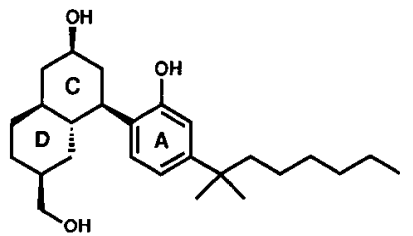

$(\cdot)-C P 55,244$
Figure 1. Chemical structures of $\Delta^{9}-\mathrm{THC}$ and 5 synthetic cannabinoids. According to the nomenclature of Johnson and Melvin (1986), $\Delta^{9}$-THC, CP42,096, and CP50,835 are defined as members of the ABCtricyclic cannabinoid class. CP47,497 is a simple AC-bicyclic cannabinoid, and CP55,940 is a hydroxypropyl analog of CP47,497. CP55,244 is an ACD-tricyclic cannabinoid with a rigidly positioned hydroxypropyl moiety. All compounds, except CP42,096, are optically active and drawn in the correct absolute configuration. CP42,096 is a racemic mixture of 2 diastereomers (ratio 1:1) with relative stereochemistry as drawn.

The availability of the nonclassical compounds revolutionized the study of the biochemical basis of cannabinoid activity. Howlett's group used them in neuroblastoma cell lines to show inhibition of adenylate cyclase activity (Howlett et al., 1988). Such inhibition is enantioselective, and the pharmacological profile correlates well with that observed by Martin's group, which showed similar orders of potencies for the compounds in tests of mouse spontaneous activity, catalepsy, body temperature, and analgesia (Little et al., 1988).

Next, one of the nonclassical compounds, CP55,940, was tritiated and used by Howlett's group to identify and fully characterize a unique cannabinoid receptor in membranes from rat brain (Devane et al., 1988). The results from the centrifugation assay showed that ${ }^{3} \mathrm{H}$-CP55,940 receptor binding is saturable, has high affinity and enantioselectivity, and exhibits characteristics expected for a neuromodulator receptor associated with a guanine nucleotide regulatory $(G)$ protein.

Recently, we partially characterized and validated the binding of ${ }^{3} \mathrm{H}-\mathrm{CP} 55,940$ in slide-mounted brain sections and described assay conditions to autoradiographically visualize the CNS distribution of cannabinoid receptors in a number of mammals, including humans (Herkenham et al., 1990). In the present study, we more fully characterize the binding and show a complete mapping of cannabinoid receptors in the rat brain using quantitative receptor autoradiography.

\section{Materials and Methods}

The procedures used were described previously (Herkenham et al., 1990; Herkenham, 1991). Optimization, kinetic, and competition studies were carried out using slide-mounted 30- $\mu$ mi-thick minced and molded rat brain "sausage" sections (Rothman et al., 1983). Sections (from male Sprague-Dawley rats) were thaw mounted onto gelatin-coated ("subbed") slides, dried briefly on a hot plate at $30^{\circ} \mathrm{C}$, and stored in air-tight boxes at $-35^{\circ} \mathrm{C}$ prior to use.

${ }^{3} \mathrm{H}-(-)$-CP55,940 (specific activity, $76 \mathrm{Ci} / \mathrm{mmol}$ ) was custom radiolabeled at Dupont New England Nuclear (NEN) by tritium reduction of (-)-CP60,106 (Devane et al., 1988) and purified (Herkenham et al., 1990). Other cannabinoids were obtained from Pfizer, Inc. Their names and stereochemical configurations are shown in Figure 1. Incubations and washes were in polyethylene cytomailers (CMS), each containing 8 sections on 4 slides in $10 \mathrm{ml}$ of solution (Herkenham, 1988). At the end of the wash period, slides were transferred to stainless-steel slide racks ( 30 slides/rack) and blown dry with slightly warm air from a hair dryer. Slides were scored and broken; the section-laden slide fragments were placed into vials, and $10 \mathrm{ml}$ of detergent-fluor (Aquassure, NEN) was added. After equilibrating overnight, the radioactivity was counted by liquid scintillation spectrofluorometry.

Cannabinoids are extremely hydrophobic (Garrett and Hunt, 1974), so preliminary studies were performed to determine how to avoid ligand adherence to glass and plastic surfaces. The disposition of ligand during pipetting and dilution steps was checked in mock assays in which either ${ }^{3} \mathrm{H}-\mathrm{CP} 55,940$ or ${ }^{3} \mathrm{H}-\Delta^{9}-\mathrm{THC}$ (specific activity, $0.07 \mathrm{Ci} / \mathrm{mmol}$; provided by National Institute of Drug Abuse) was substituted for cold drug, and the solutions were assayed for radioactivity by scintillation counting. Tests were performed using "subbed" pipctte tips and "subbed" cytomailers, and plain glass or silanized glass test tubes in place of cytomailers. Using solutions prepared according to the optimized assay conditions (see below), we found no differences between calculated and observed radioactivity in the initial pipetting from source containers or throughout the cascade of mock dilutions when using the untreated polyethylene tips and cytomailers, so protective coatings were deemed unnecessary.

Autoradiography was performed on 15 - $\mu \mathrm{m}$-thick sections of rat brain (male Sprague-Dawley; $n=12$ ). Serial sections were saved for total binding, nonspecific binding, and counterstaining with cresyl violet. Binding conditions were incubation at $37^{\circ} \mathrm{C}$ for $2-3 \mathrm{hr}$ in $50 \mathrm{~mm}$ Tris$\mathrm{HCl}$ buffer $(\mathrm{pH}, 7.4)$ with $5 \%$ bovine serum albumin (BSA) and $10 \mathrm{nM}$ ${ }^{3} \mathrm{H}-\mathrm{CP} 55,940$. Washing was at $0^{\circ} \mathrm{C}$ for $4 \mathrm{hr}$ in the same buffer with $1 \%$ BSA. Following a $5-\mathrm{min}$ immersion in $0.5 \%$ formaldehyde in Tris- $\mathrm{HCl}$ buffer at $24^{\circ} \mathrm{C}$ and subsequent brief dip in deionized water, sections were blown dry. Slides were placed in x-ray cassettes (Wolf) and exposed to tritium-sensitive film (LKB or Amersham) for 1-3 weeks before developing (Kodak D-19). Sections were coexposed with tritium standards (Amersham high-density Micro-scales).

Developed films were illuminated with a light box (Northern Light) and digitized with a solid state videocamera (Sierra Scientific) and Macintosh II computer-based system for quantitative densitometry using IMAGE software (Wayne Rasband, Research Services, Branch, NIMH). Transmittance levels were converted to $\mathrm{nCi} / \mathrm{mg}$ tissue wet weight using a best-fit polynomial equation relating transmittance levels to tissue equivalent values provided by Amersham. Binding was expressed as $\mathrm{pmol}$ bound/mg protein based on the known values of specific activity of the isotope, decay of standards, and the ratio of $\mathrm{mg}$ protein $/ \mathrm{mg}$ tissue (approximately $1 / 10$ ). Brain structures appearing on the monitor were outlined by mouse control for determination of average density. Outlining was guided by reference to the corresponding Nissl-stained section and a rat brain atlas (Paxinos and Watson, 1982). Right and left sides were pooled from 2-6 sections containing each structure, and the measures were averaged. The process was performed on images incubated for total and for nonspecific binding, and the difference was computed to determine specific binding for each structure (Table 1).

\section{Results}

\section{Binding characteristics}

Preliminary binding studies were carried out to determine appropriate buffer type and $\mathrm{pH}$, effects of salts and preincubation in various media, optimal incubation time and temperature, and optimal postincubation wash time. Initial experiments, carried out in incubations with 2-3 nM ${ }^{3} \mathrm{H}-\mathrm{CP} 55,940$ at $24^{\circ} \mathrm{C}$ for $2 \mathrm{hr}$, revealed that the best binding (around 70\% specific) was 
Table 1. Regional distribution of cannabinoid receptors in rat brain

Specific binding (pmol/mg

Structure protein)

Olfactory areas

Ependymal and subependymal layer and olfactory ventricle

Internal granular and plexiform and mitral cell layers

External plexiform layer

Glomerular layer

Olfactory nerve layer

Accessory olfactory bulb

Anterior olfactory nuclei

Olfactory tubercle

White matter tracts

Anterior commissure, intrabulbar

Corpus callosum

Internal capsule

Fimbria

Stria terminalis

Cerebral cortex

Cingulate cortex, (prelimbic) area 3

Frontal (motor) cortex, areas 1-3

Parietal (somatosensory I) cortex

Occipital (visual 1) cortex

Occipital (visual II) cortex

Temporal (auditory) cortex

Entorhinal cortex

Granular retrosplenial cortex

Hippocampal formation

Dentate gyrus molecular layer

Dentate gyrus hilus

Field CA3 of Ammon's horn

Field CAl of Ammon's hom

Dorsal subiculum

Basal ganglia

Accumbens nucleus

Caudate-putamen, medial

Caudate-putamen, lateral

Globus pallidus

Ventral pallidum

Entopeduncular nucleus

Substantia nigra pars reticulata

Ventral tegmental area

$4.32 \pm 0.79$

$2.89 \pm 0.48$

$0.57 \pm 0.10$

$0.65 \pm 0.07$

$0.42 \pm 0.02$

$0.77 \pm 0.19$

$2.48 \pm 0.33$

$1.60 \pm 0.09$

$3.29 \pm 0.24$

$0.57 \pm 0.10$

$0.30 \pm 0.06$

$0.70 \pm 0.09$

$1.51 \pm 0.11$

$2.26 \pm 0.18$

$2.68 \pm 0.27$

$2.10 \pm 0.29$

$1.72 \pm 0.28$

$1.72 \pm 0.31$

$1.45 \pm 0.32$

$1.52 \pm 0.22$

$1.70 \pm 0.28$

$4.09 \pm 0.23$

$2.92 \pm 0.09$

$4.05 \pm 0.16$

$3.19 \pm 0.26$

$3.08 \pm 0.31$

$2.27 \pm 0.42$

$2.47 \pm 0.30$

$4.33 \pm 0.43$

$6.42 \pm 0.50$

$1.56 \pm 0.25$

$5.44 \pm 0.45$

$6.33 \pm 0.13$

$1.46 \pm 0.29$

$2.43 \pm 0.35$

$2.13 \pm 0.08$

Medial septum and nuclei of the diagonal band

Lateral septum

Amygdala

Medial amygdaloid nucleus

Basolateral amygdaloid nucleus

Central amygdaloid nucleus

Nucleus of the lateral olfactory tract
Table 1. Continued

\begin{tabular}{|c|c|}
\hline Structure & $\begin{array}{l}\text { Specific binding } \\
\text { (pmol/mg } \\
\text { protein) }\end{array}$ \\
\hline \multicolumn{2}{|l|}{ Diencephalon } \\
\hline Medial preoptic area & $1.75 \pm 0.30$ \\
\hline Suprachiasmatic nucleus & $0.97 \pm 0.20$ \\
\hline Supraoptic nucleus & $0.90 \pm 0.16$ \\
\hline Paraventricular hypothalamic nucleus & $1.28 \pm 0.19$ \\
\hline Median eminence & $0.58 \pm 0.15$ \\
\hline Ventromedial hypothalamic nucleus (VMH) & $1.58 \pm 0.15$ \\
\hline Latcral hypothalamus (LH) & $1.87 \pm 0.22$ \\
\hline Mammillary nuclei (MM/ML) & $1.90 \pm 0.35$ \\
\hline Dorsal thalamus & $1.33 \pm 0.20$ \\
\hline Medial habenula & $1.13 \pm 0.22$ \\
\hline Lateral habenula & $1.93 \pm 0.39$ \\
\hline \multicolumn{2}{|l|}{ Brain stem } \\
\hline Central gray substance & $1.89 \pm 0.37$ \\
\hline Oculomotor nucleus & $0.47 \pm 0.07$ \\
\hline Red nucleus & $0.66 \pm 0.16$ \\
\hline Interpeduncular nucleus & $0.89+0.07$ \\
\hline Interpeduncular nucleus, lateral subnucleus & $2.07 \pm 0.44$ \\
\hline Pontine nuclei & $0.91 \pm 0.30$ \\
\hline Superior colliculus & $1.47 \pm 0.16$ \\
\hline Inferior colliculus & $0.89 \pm 0.24$ \\
\hline Median raphe nucleus & $1.06 \pm 0.13$ \\
\hline Cuneiform nucleus & $1.79 \pm 0.39$ \\
\hline Parabrachial nucleus & $2.00 \pm 0.23$ \\
\hline Locus coeruleus & $1.48 \pm 0.25$ \\
\hline Pontine reticular nucleus, caudal & $0.65 \pm 0.08$ \\
\hline Vestibular nuclei & $0.27 \pm 0.14$ \\
\hline Dorsal cochlear nucleus & $1.45 \pm 0.37$ \\
\hline Nucleus of the solitary tract, rostral & $1.79 \pm 0.36$ \\
\hline Nucleus of the solitary tract, caudal & $2.43 \pm 0.45$ \\
\hline Inferior olive & $1.20 \perp 0.01$ \\
\hline Ambiguus nucleus & $1.14 \pm 0.21$ \\
\hline Area postrema & $1.18 \pm 0.31$ \\
\hline Hypoglossal nucleus & $1.44 \pm 0.43$ \\
\hline Spinal trigeminal nucleus & $0.80 \pm 0.20$ \\
\hline Gracile and cuneate nuclei & $0.74 \pm 0.13$ \\
\hline \multicolumn{2}{|l|}{ Cerebellum } \\
\hline Molecular layer & $4.19 \pm 0.35$ \\
\hline Granule layer & $0.96 \pm 0.27$ \\
\hline Deep nuclei & $0.23 \pm 0.14$ \\
\hline \multicolumn{2}{|l|}{ Cervical spinal cord } \\
\hline Substantia gelatinosa (layers 1,2 ) & $0.95 \pm 0.22$ \\
\hline Lamina $X$ (layer 10) & $1.08 \pm 0.31$ \\
\hline Ventral horn (layers 7-9) & $0.60 \pm 0.08$ \\
\hline \multicolumn{2}{|l|}{ Pituitary } \\
\hline Neural lobe & $0.33 \pm 0.15$ \\
\hline Anterior lobe & $0.15 \pm 0.08$ \\
\hline
\end{tabular}

The data were taken from films exposed for 3 weeks. Similar results were obtained from films exposed for $8 \mathrm{~d}$. The amounts bound reflect equilibrium binding of 10 nM ${ }^{3} \mathrm{H}-\mathrm{CP} 55,940$; assuming a $K_{d}$ of approximately $15 \mathrm{nM}$, about $40 \%$ of the receptors would be occupied.

from Pfizer) in the incubation medium. Incubations without BSA gave no specific binding at all-counts were actually lower in the total than in the nonspecific condition (total, $8900 \mathrm{cpm} /$ section; nonspecific, $10,700 \mathrm{cpm} / \mathrm{section}$ ).

Binding was relatively unaffected by preincubation in Tris produced by incubation in $50 \mathrm{~mm}$ Tris- $\mathrm{HCl}$ buffer ( $\mathrm{pH} 7.4)$ with $5 \%$ BSA (Sigma; reagent grade worked as well as fatty-acid-free BSA). Washes were at $0^{\circ} \mathrm{C}$ for $4 \mathrm{hr}$ in the same Tris buffer with $1 \%$ BSA. Nonspecific binding was determined by inclusion of $10 \mu \mathrm{M}$ CP55,244 (the most potent cannabinoid in the CP series 
Figure 2. Association and dissociation curves of $10 \mathrm{~nm}{ }^{3} \mathrm{H}$-CP55,940 binding to rat brain "sausage" sections were determined by liquid scintillation counting. Total and nonspecific binding was determined at each time point. The data are expressed as the percentage of total specific binding (at equilibrium). According to Bylund (1980), $K_{\mathrm{ob}}(0.012$ $\mathrm{min}^{-1}$ ) was determined from the slope of $\ln \left(B_{c}-B\right)$ versus time, where $B_{e}$ is the binding equilibrium; $k_{.1}$ was determined from the slope of $\ln \left(B / B_{n}\right)$ versus time, where $B_{o}$ is the amount bound at equilibrium; and $k_{+1}=\left(K_{\circ b}\right.$ $\left.-K_{-1}\right) / L_{r}$, where $L_{t}$ is the ligand concentration. The data points are from a single experiment and represent the difference of total and nonspecific binding, each determined by the average of 8 sections counted separately, typically with less than $15 \%$ variability.
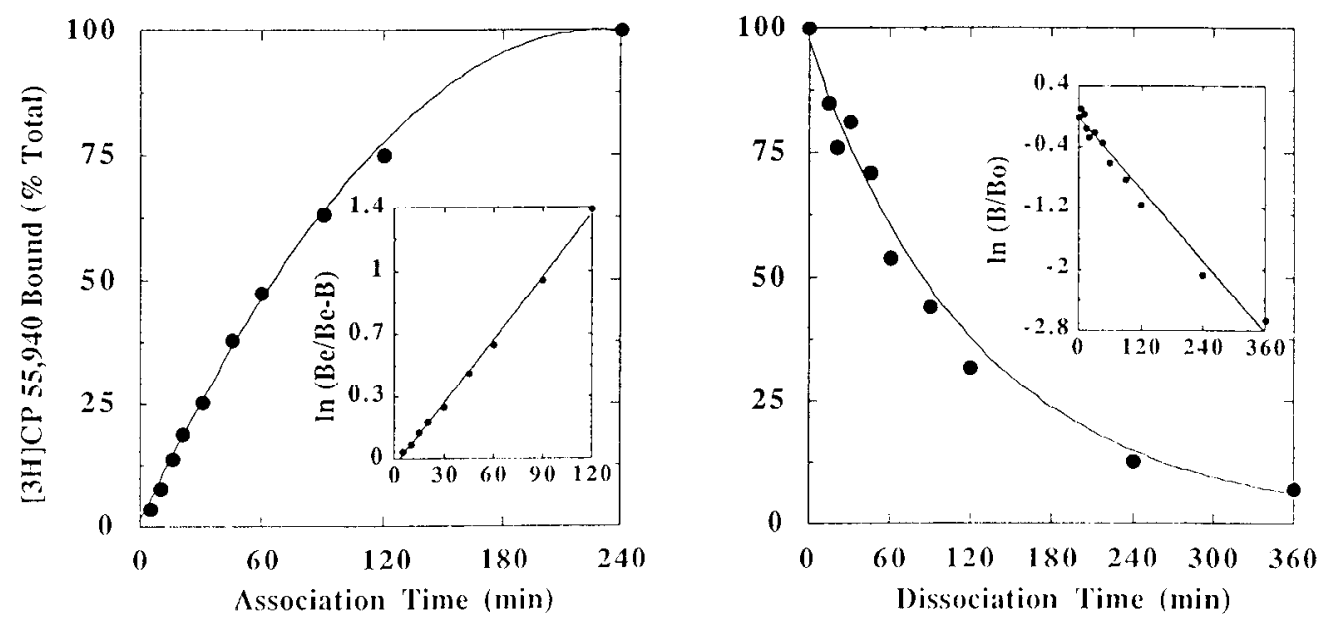

buffer with $100 \mathrm{mM} \mathrm{NaCl}$ for $30 \mathrm{~min}$, at either $0^{\circ} \mathrm{C}$ or $24^{\circ} \mathrm{C}$, or by the inclusion of $100 \mathrm{~mm} \mathrm{NaCl}$ in the incubation medium. Incubations in $10 \%$ BSA gave lower total and lower specific binding. Binding was reduced by use of other buffers (potassium phosphate, HEPES, MOPS) or by increases or decreases in $\mathrm{pH}$ or Tris-HCl buffer concentration. The optimal wash condition was $4 \mathrm{hr}$ in Tris buffer with $1 \% \mathrm{BSA}$ at $0^{\circ} \mathrm{C}$. Washes at $0^{\circ} \mathrm{C}$ for $>4 \mathrm{hr}$ or washes at $24^{\circ} \mathrm{C}$ for $1 \mathrm{hr}$ gave lower specific binding. Specific binding was reduced by wash with $0.1 \%$ BSA (higher nonspecific), whereas $1 \%$ and $5 \%$ BSA in the wash gave similar results.

The next variables to be examined were temperature and time of incubation. Virtually no binding occurred at $0^{\circ} \mathrm{C}$, binding at $24^{\circ} \mathrm{C}$ reached equilibrium at $16 \mathrm{hr}$ of incubation, and binding at $37^{\circ} \mathrm{C}$ reached equilibrium at $4 \mathrm{hr}$ and was typically $80-90 \%$ specific (with greater total binding than at $24^{\circ} \mathrm{C}$ ). At $37^{\circ} \mathrm{C}$, total binding dropped at time periods longer than $4 \mathrm{hr}$, reaching levels of nonspecific binding by $14 \mathrm{hr}$, suggesting ligand and/or recep-

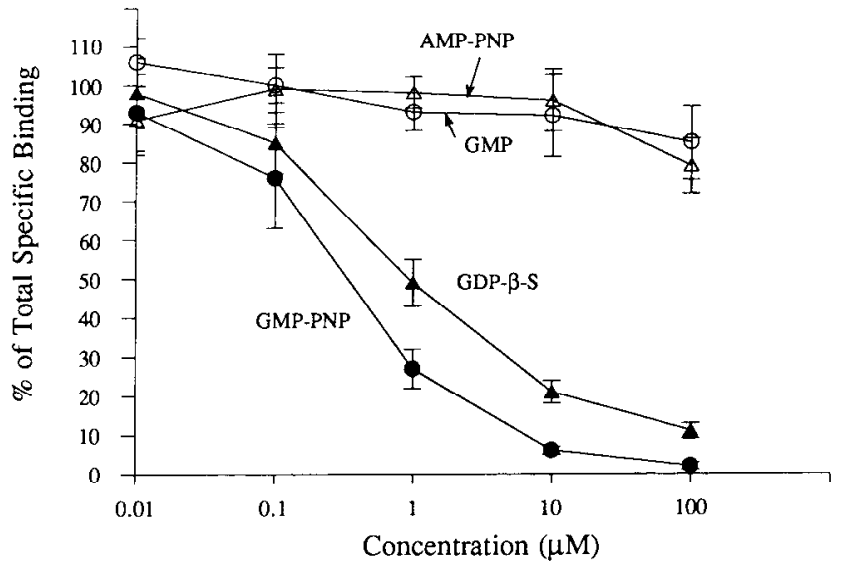

Figure 3. Effects of guanine nucleotides (sources: Sigma and Boeringer Manheim) on specific binding of $10 \mathrm{nM}^{3} \mathrm{H}-\mathrm{CP} 55,940$. Nonhydrolyzeable analogs were used for GTP, guanylylimidodiphosphate (GMP-PNP; tetra-lithium salt); GDP, guanosine 5'-O-(2-thiodiphosphate) (GDP- $\beta$ $S$ ); and ATP, adenylylimidodiphosphate (AMP-PNP). Data are means \pm SD from 3-6 experiments and are normalized to specific binding (total minus nonspecific) in the absence of nucleotides. tor degradation at this temperature (Herkenham, 1990). In preincubation tests, sections that were placed in nonradioactive incubation solution at $37^{\circ} \mathrm{C}$ for $2.5 \mathrm{hr}$ and washed at $0^{\circ} \mathrm{C}$ for 4 hr before incubation had $80 \%$ of the total binding observed in sections not preincubated and prewashed, suggesting that degradation or loss of the receptor does occur in aqueous phases.

As reported previously (Herkenham, 1991), binding surface analysis (McGonigle et al., 1986; Rothman, 1986; Rothman et al., 1988) was used to determine parameters of binding with either $1 \%$ or $5 \%$ BSA in the incubation medium. Two concentrations of ${ }^{3} \mathrm{H}-\mathrm{CP} 55,940$ ( 1 and $10 \mathrm{nM}$ ) were each competitively inhibited by 12 concentrations of unlabeled CP55,940. Competitive inhibition curves were subjected to a computerized iterative curve-fitting program for determining best-fit parameter estimates $\left(K_{d}, B_{\max }\right)$. Using a single-site model, the apparent affinity $\left(K_{d}\right)$ of CP55,940 in $1 \%$ BSA was $2.6 \mathrm{nM}$, and the binding

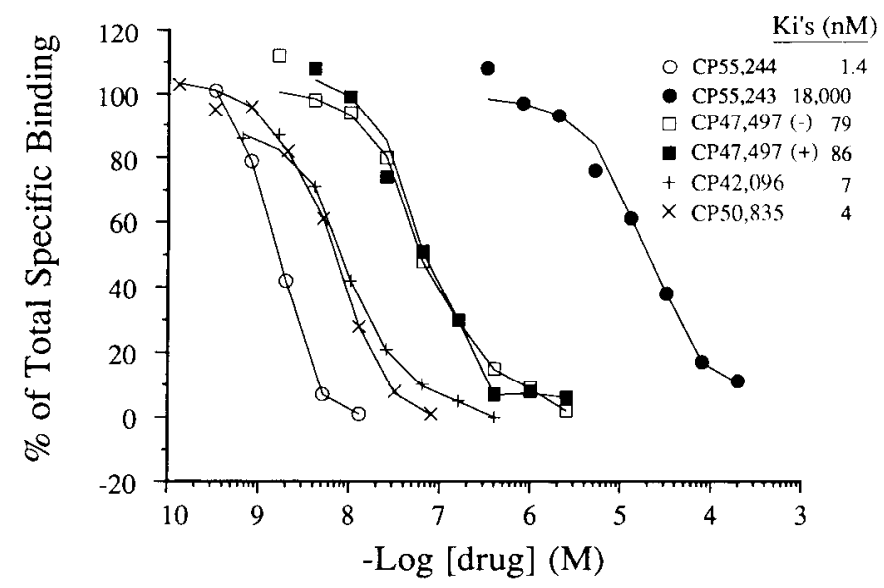

Figure 4. Competitive inhibition of $1 \mathrm{~nm}{ }^{3} \mathrm{H}-\mathrm{CP} 55,940$ binding in whole rat brain "sausage" sections by various synthetic cannabinoids at the concentrations indicated. The data are normalized to specific binding (total minus nonspecific) in absence of competitors. Nonspecific binding was determined by addition of $10 \mu \mathrm{M}$ CP55,244 (the most potent cannabinoid in the CP series; Johnson and Melvin, 1986) and typically represented $10-20 \%$ of total binding. Data points represent means of 8 determinations. The inhibition constants $\left(K_{i} s\right)$ for each of the drugs, determined by binding surface analysis, are given. 

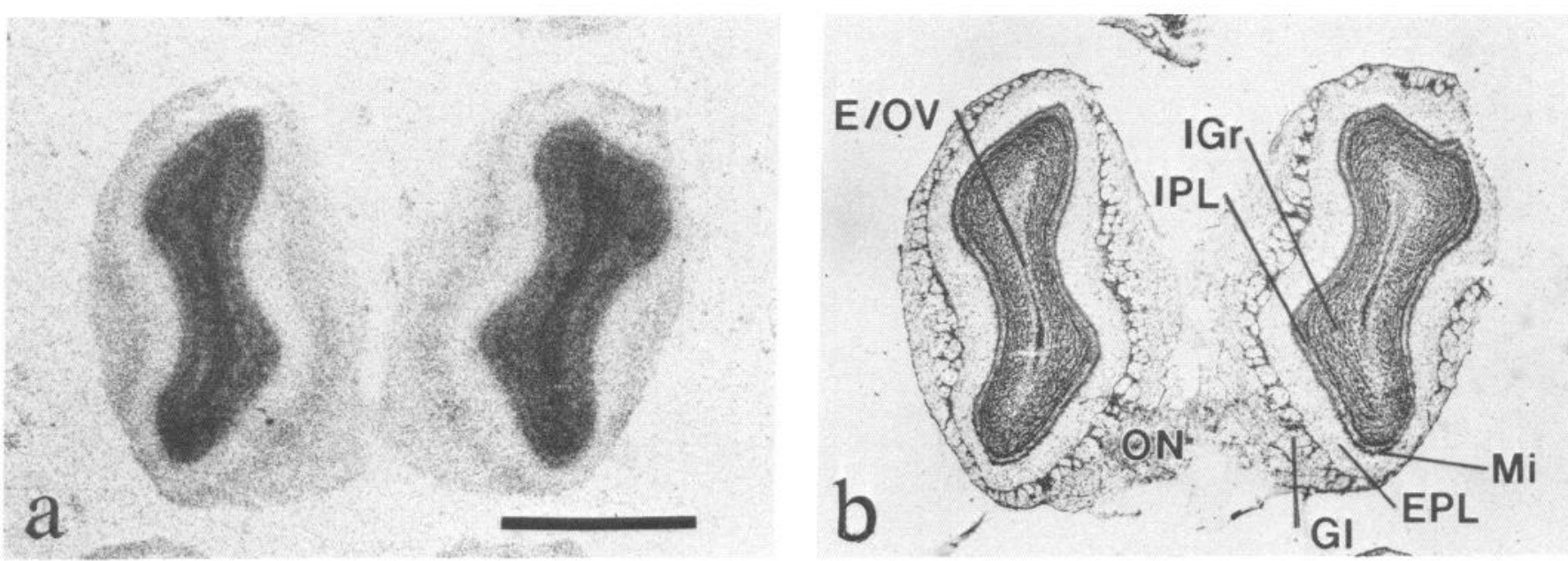

Figure 5. Autoradiography of $10 \mathrm{nM}{ }^{3} \mathrm{H}-\mathrm{CP} 55,940$ binding in the olfactory bulb $(a)$. The Nissl-stained section $(b)$ is 2 serial sections removed from the section exposed to film. See Appendix for abbreviations. Scale bar, $2 \mathrm{~mm}$ for $a$ and $b$.

capacity $\left(B_{\max }\right)$ was $1158 \mathrm{fmol} / \mathrm{mg}$ protein (Herkenham, 1991). With $5 \%$ BSA, the apparent $K_{d}$ was $15 \mathrm{~nm}$, and the $B_{\max }$ was $910 \mathrm{fmol} / \mathrm{mg}$ protein (Herkenham et al., 1990).

In order to test a large series of cannabinoid and noncannabinoid drugs for competitive inhibition of ${ }^{3} \mathrm{H}$-CP55,940 binding, the assay condition with $5 \%$ BSA was selected. This ensured that the hydrophobic cannabinoids would dissolve at the high concentrations required (at least for the drugs with low potency). Drug concentrations of $10^{-4} \mathrm{M}$ were achieved, which are much higher than the limit of solubility of cannabinoids in water or buffer without a carrier such as BSA (Garrett and Hunt, 1974; Bach et al., 1976). We also found that variability of binding was reduced in the $5 \%$ BSA condition as opposed to $1 \%$ (data not shown).

The kinetics of association and dissociation were determined using the optimal assay conditions $\left(10 \mathrm{nM}{ }^{3} \mathrm{H}-\mathrm{CP} 55,940\right.$ in 50 mм Tris- $\mathrm{HCl}, \mathrm{pH} 7.4$, with $5 \% \mathrm{BSA}$ at $37^{\circ} \mathrm{C}$ ). The experiment was performed on parallel sets of sausage sections; one set was counted by liquid scintillation spectrofluorometry, and another was exposed to film for quantitative autoradiographic analysis. From scintillation counts, the association rate constant $\left(k_{+1}\right)$, determined by a pseudo first-order method (Bylund, 1980), was $0.00038 \mathrm{~min}^{-1} \cdot \mathrm{nM}^{-1}$ (Fig. 2). The dissociation rate constant $\left(k_{-1}\right)$, determined by infinite dilution after equilibrium binding, was $0.0079 \mathrm{~min}^{-1}$ (Fig. 2). The equilibrium dissociation constant $\left(K_{d}\right.$ $=k_{-1} / k_{+1}$ ) was $21 \mathrm{~nm}$. From densitometry, the $k_{+1}$ was 0.0011 $\min ^{-1} \cdot \mathrm{nM}^{-1}$, the $k_{-1}$ was $0.0056 \mathrm{~min}^{-1}$, and the $K_{d}$ was $5.2 \mathrm{~nm}$. These values are in fairly close agreement with the $K_{d}$ of $15 \mathrm{~nm}$ determined by competitive inhibition (Herkenham et al., 1990).

The relationship of cannabinoid receptor binding to G-proteins was examined in a set of experiments in which a range of concentrations of guanine nucleotides was added to the incubation solution. The results (Fig. 3) showed that the nonhydrolyzable GTP analog guanylylimidodiphosphate (GMP-PNP) profoundly inhibits binding of $10 \mathrm{nM}{ }^{3} \mathrm{H}-\mathrm{CP} 55,940$ in a dosedependent fashion, and the GDP analog guanosine $5^{\prime}-\mathrm{O}-(2-$ thiodiphosphate) (GDP- $\beta$-S) inhibits binding with about $1 / 10$ the potency. Both GMP and the nonhydrolyzable ATP analog adenylylimidodiphosphate (AMP-PNP) failed to inhibit binding at concentrations as high as $100 \mu \mathrm{M}$.

The competition curves (Fig. 4) for some of the synthetic cannabinoid compounds provided data for determination of inhibition constants $\left(K_{i} \mathrm{~s}\right)$. Similar analysis of a much larger series of natural and synthetic cannabinoids was reported previously (Herkenham et al., 1990). As shown in Figure 1, (-)$\mathrm{CP} 42,096$ is a tricyclic cannabinoid with an $\mathrm{ABC}$ ring structure similar to that of $\Delta^{9}$-THC, with a modification of the alkyl side chain at the C-3 position (Johnson and Melvin, 1986; Howlett et al., 1988). (-)-CP50,835 is $N$-methyllevonantradol. Levonantradol has been extensively studied in clinical trials for its potential use as an analgesic (Johnson and Melvin, 1986). (-)CP47,497 and (+)-CP47,497 are optically pure forms of $( \pm)$ $\mathrm{CP} 47,497$, the simplest biologically active bicyclic cannabinoid compound (Melvin et al., 1984; Johnson and Melvin, 1986; Howlett et al., 1988). Finally, CP55,244 and CP55,243 are (-) and $(+)$ forms, respectively, of the more rigid ACD tricyclic compounds that show high enantioselectivity. The 10,000-fold difference in potency of the 2 forms has been shown and discussed previously (Johnson and Melvin, 1986; Howlett et al., 1988; Herkenham et al., 1990).

\section{Anatomical distributions}

The autoradiographic distribution of cannabinoid receptors in rat brain is shown in Figures 5-14. Densitometry (Table 1) was performed on animal cases numbered 19-21, which are those presented in the coronal plane. Cases prepared before these show similar patterns of receptor labeling but typically have higher levels of nonspecific binding and inferior tissue quality. Factors contributing to optimization include working with a new batch of radiolabeled ligand (following partial degradation and loss of specific activity in the first batch due to storage in a concentration that was too high for stability), cutting thinner sections and rapidly drying them, and insertion of the formaldehyde and water rinses at the end of the washing step (this mild fixation procedure tended to prevent the sections from partially detaching from the slides, improving the tissue quality without altering binding characteristics). Variants that did not improve autoradiography included achieving isotonicity by adding $\mathrm{NaCl}$ or sucrose to the incubations and wash solutions and varying the slide preparation and section drying procedures.

In the descriptions that follow, specific terms are used to describe the following ranges of binding densities (in $\mathrm{pmol} / \mathrm{mg}$ 

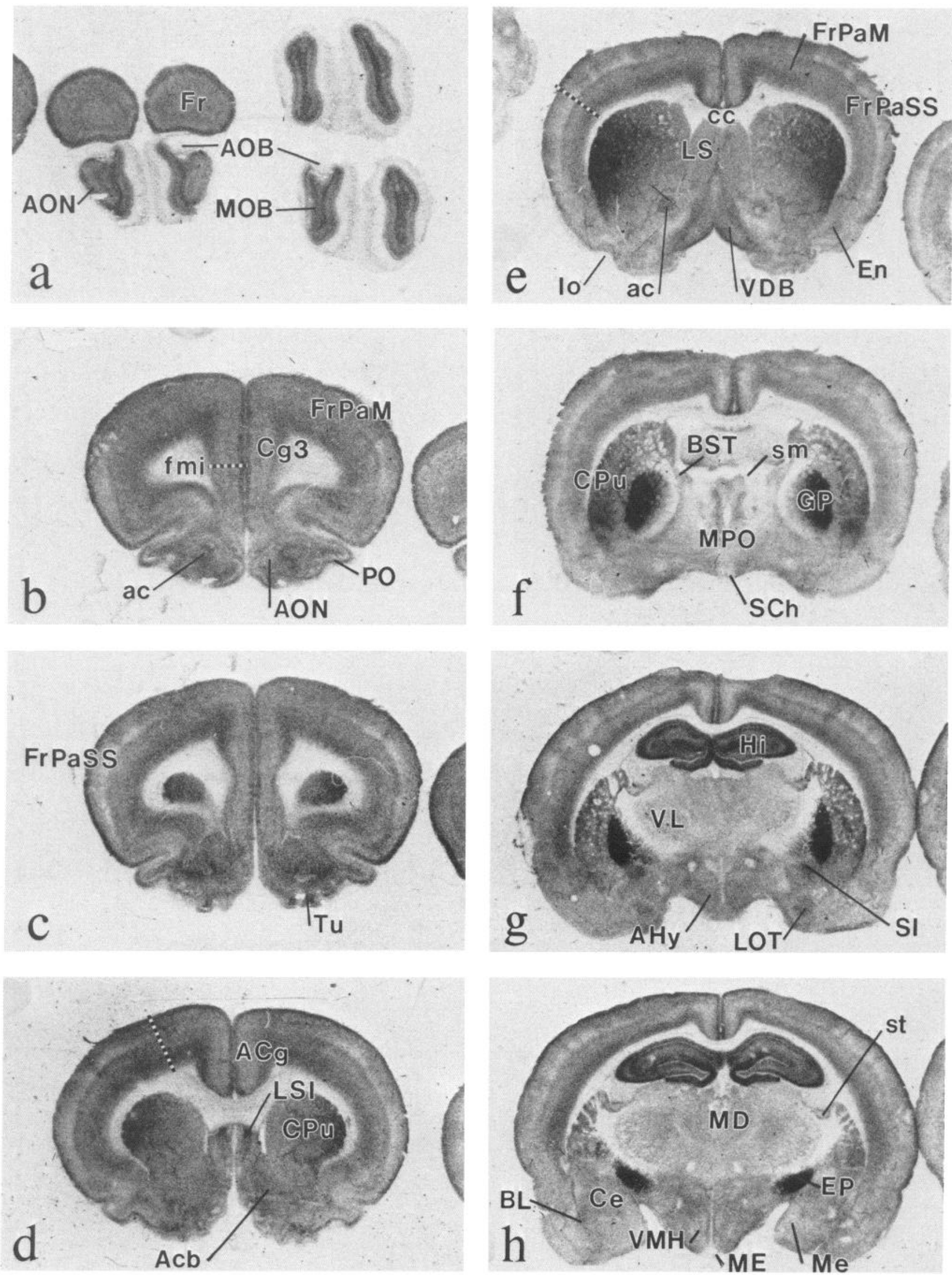

Figure 6. Autoradiography of $10 \mathrm{~nm}{ }^{3} \mathrm{H}-\mathrm{CP} 55,940$ binding in selected coronal sections taken from cases $19-21$. Dashed lines in $d, e, l$, and $m$ show locations of computer-generated density plots shown in Figure 8. NS in $K$ shows nonspecific binding at $j$ level. See Appendix for abbreviations. Scale bar, $2 \mathrm{~mm}$ for $a-p$. 

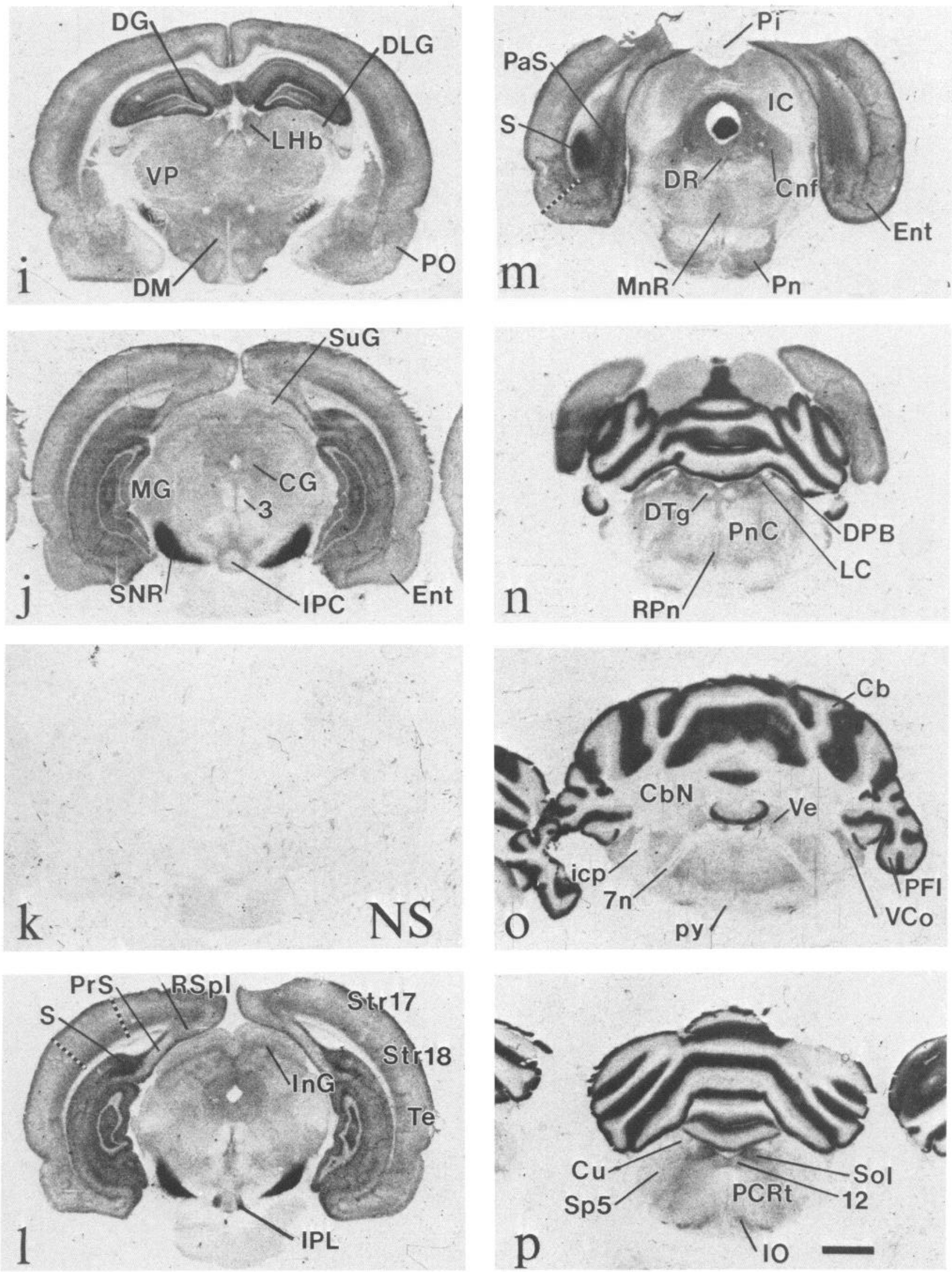

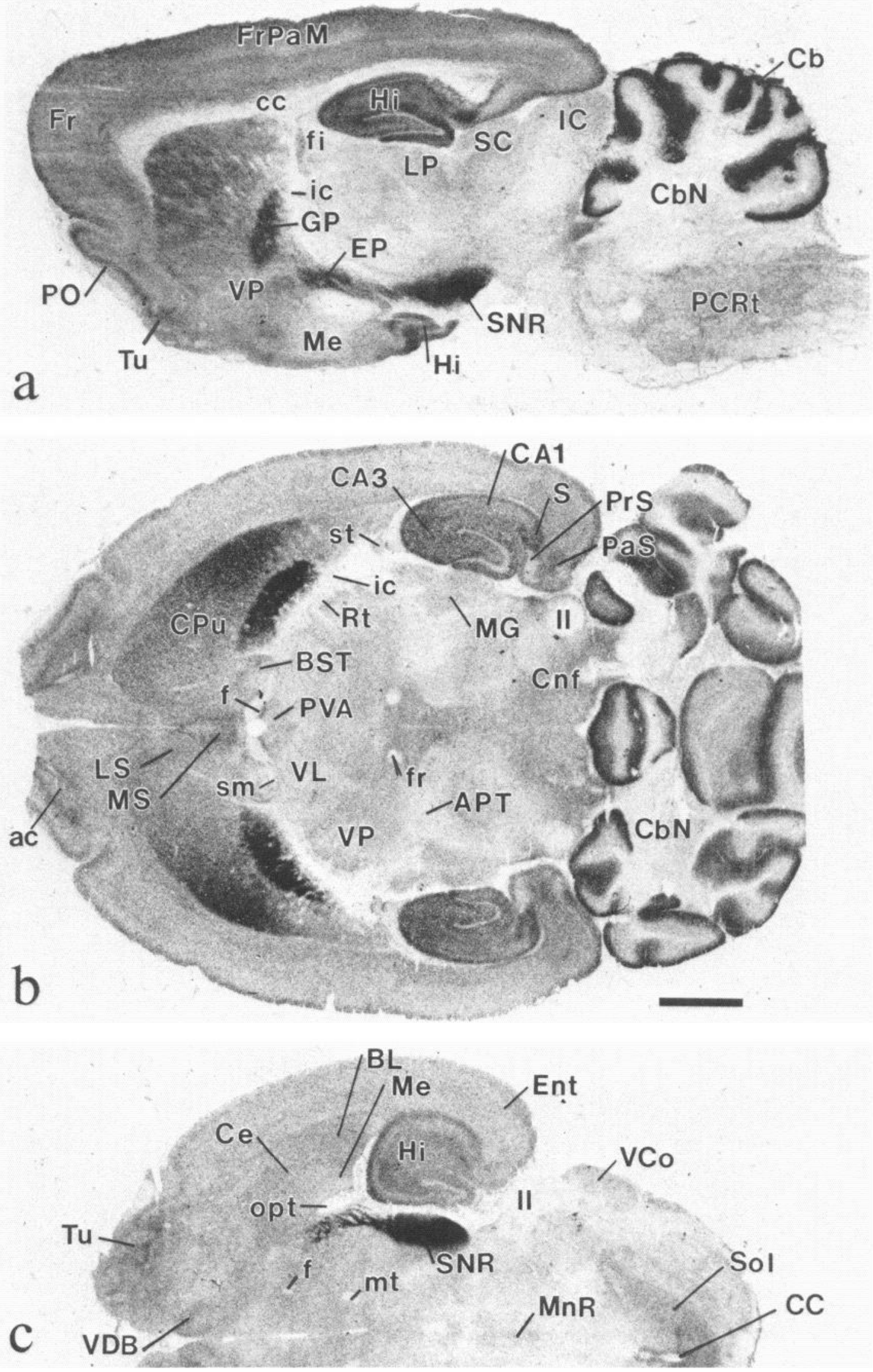

Figure 7. Autoradiography of $10 \mathrm{nM}{ }^{3} \mathrm{H}-\mathrm{CP} 55,940$ binding in sagittal $(a)$ and horizontal $(b, c)$ sections selected to show overall distribution of cannabinoid receptors but especially the patterns of dense distribution in the outflow nuclei of the basal ganglia. See Appendix for abbreviations. Scale bar, $2 \mathrm{~mm}$ for $a-c$. 
AGRANULAR CORTEX
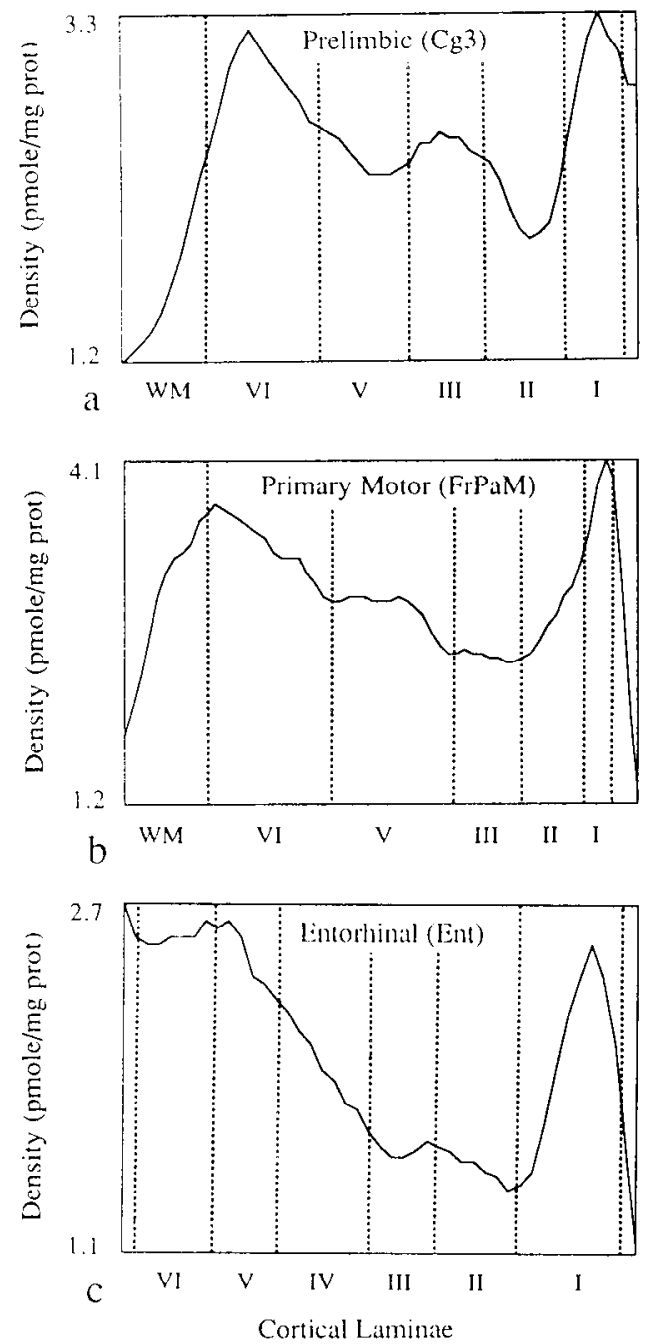

GRANULAR CORTEX
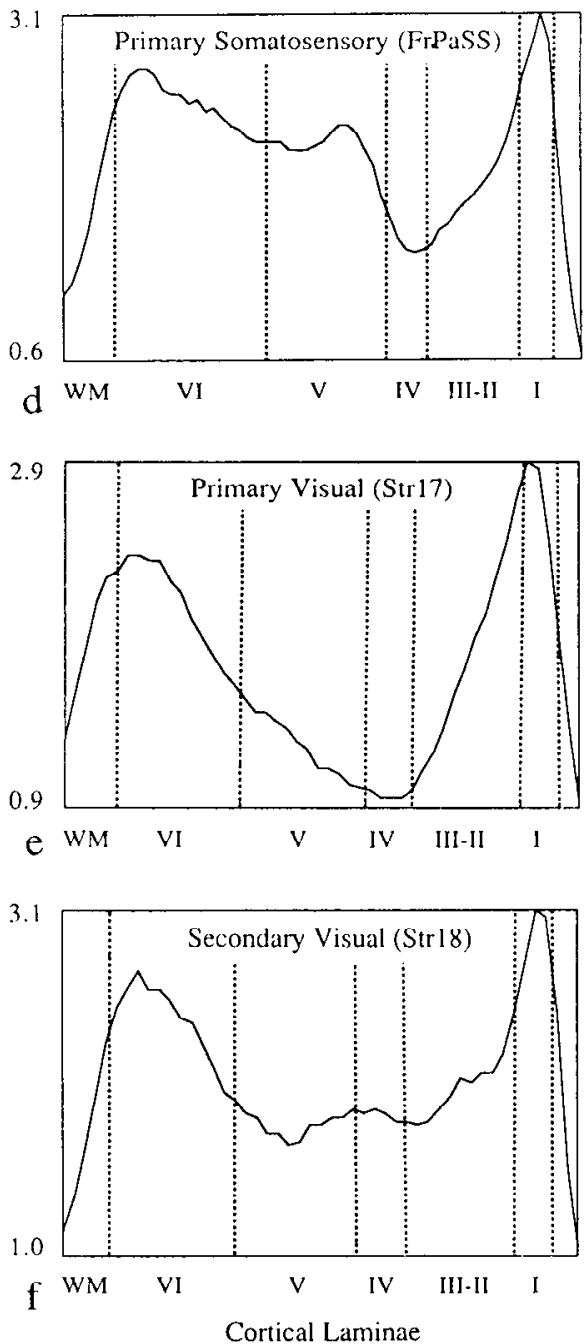

Figure 8. Plots of binding level as a function of cortical depth in 6 areas of cortex. The areas selected for computer-generated density plots are shown as dashed lines in Figure $6 b,(C g 3), 6 d$ (FrPaM), 6e (FrPaSS), 6l (Strl7 and $S t r 18)$, and $6 m(E n t)$. Cortical layers $(I-V I)$ and subcortical white matter ( $W M$ ) were positioned on the plots by projecting the image of the corresponding Nissl-stained section onto the plots and marking the location of the layer boundaries. See Appendix for abbreviations. The width of the measured column was approximately $100 \mu \mathrm{m}$. Magnifications vary in each plot. Lengths of abscissas: $a, 300 \mu \mathrm{m} ; b, 470$ $\mu \mathrm{m} ; c, 300 \mu \mathrm{m} ; d, 450 \mu \mathrm{m} ; e, 350 \mu \mathrm{m}$; $f, 350 \mu \mathrm{m}$ protein): very dense, $>4$; dense, $3-4$; moderate, $2-3$; sparse, $1-$ 2 ; and very sparse, $<1$. The actual densitometric values for most structures described are given in Table 1 .

Olfactory areas. In the main olfactory bulb, laminar patterns of binding corresponded with bulbar architecture. Very dense binding filled the ependymal and subependymal zones at the center of the bulb. Surrounding this was moderate binding in the cell-rich inner layers, including the granule and mitral layers. A slight decrement in density occurred in the internal plexiform layer. Very sparse binding characterized the external plexiform and glomerular layers and the olfactory nerve, though the glomerular layer was slightly elevated (Fig. 5). All portions of the accessory olfactory bulb had very sparse binding (Fig. 6a). The anterior olfactory nuclei had moderate binding that was rather evenly distributed (Figs. $6 a, b ; 7 b$ ). Throughout its extent, the olfactory portion of the anterior commissure had dense binding (Figs. $6 a-e, 7 b$ ), whereas the lateral olfactory tract had very sparse binding (Fig. $6 b-e$ ). The primary olfactory (piriform) cortex had moderate binding rostrally, enriched in the deep half of the molecular layer (layer Ib) in the vicinity of the lateral olfactory tract (Fig. $6 b-d$ ), but overall, it and the olfactory tubercle had only sparse binding (Figs. $6 d-i, 7 a, c$ ).
Forebrain, neocortex. Binding in the cerebral cortex was somewhat evenly distributed, and the variations in density corresponded to both areal and laminar features of cortical architecture. A rostral-to-caudal/ventral gradient of density was observed, with the frontal, parietal, and cingulate areas showing moderate binding, and the striate, temporal, retrosplenial, and entorhinal areas showing sparse binding (Figs. 6, 7). The general feature of laminar distribution in all cortical areas was a bilaminar pattern with peaks in layers I and VI and lower binding in the intermediate layers. However, changes in binding levels were not abrupt and, therefore, did not closely correspond with laminar borders (Fig. 8). A notable exception was found in the prelimbic cortex $(\mathrm{Cg} 3)$, where the peak in layer I was quite pronounced and an additional elevation was seen in layer III (Fig. 8). Another clear association of changes in binding levels with lamination patterns was found in the primary somatosensory cortex (FrPaSS), where a trough of binding closely correlated with granular portions of layer IV and an intermediate peak was situated over layer Va (Fig. 8).

Forebrain, hippocampal formation. The hippocampal formation showed strikingly dense binding relative to the rest of the cortex (Figs. 6, 7, 9). The dentate gyrus molecular layer had 

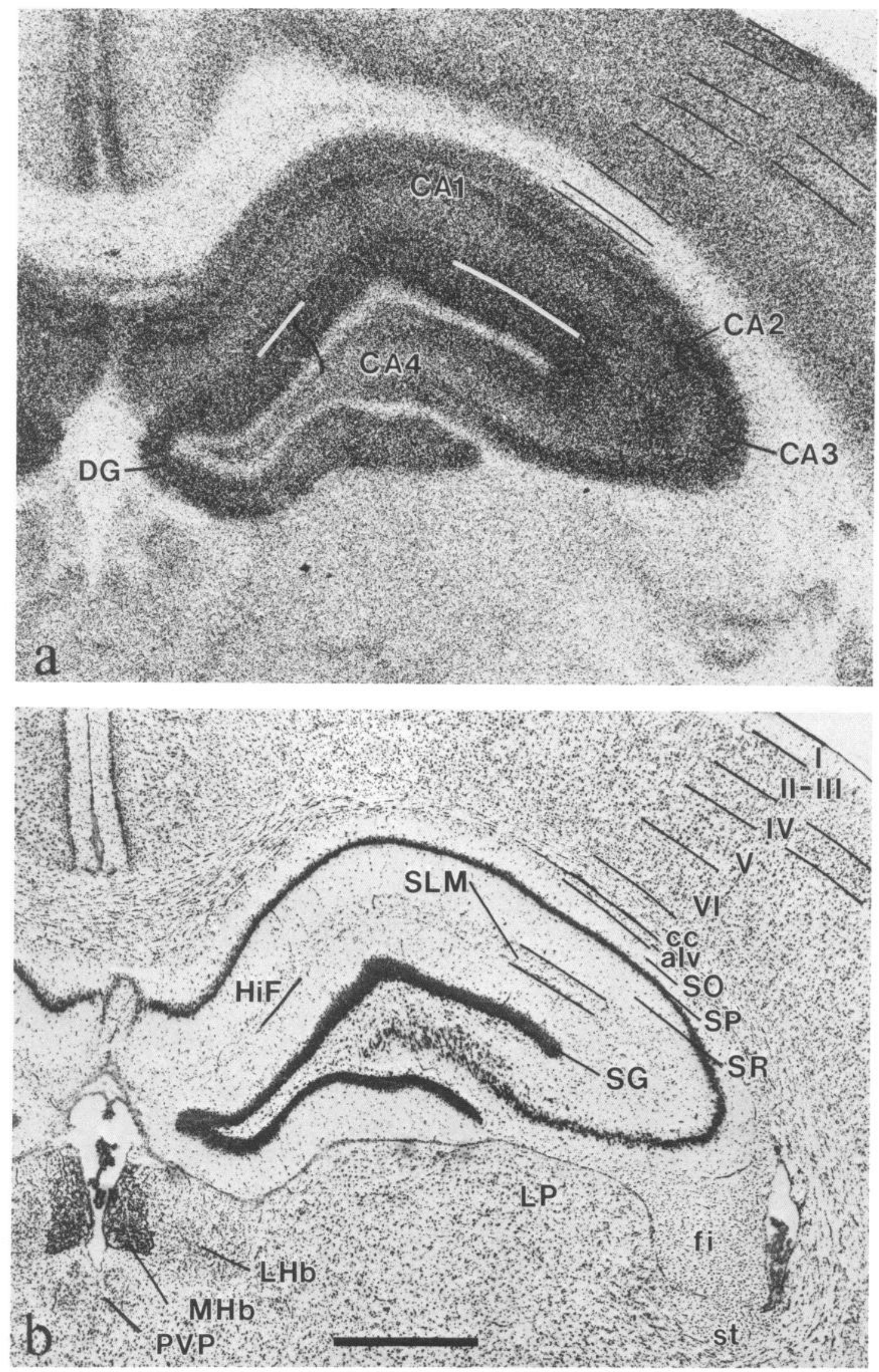

Figure 9. Autoradiography of $10 \mathrm{~nm}{ }^{3} \mathrm{H}-\mathrm{CP} 55,940$ binding in the dorsal hippocampus. Locations of neocortical and hippocampal layers are marked by lines in both the autoradiograph $(a)$ and the corresponding Nissl-stained section $(b)$. See Appendix for abbreviations. Scale bar, 1 mm for $a$ and $b$. 

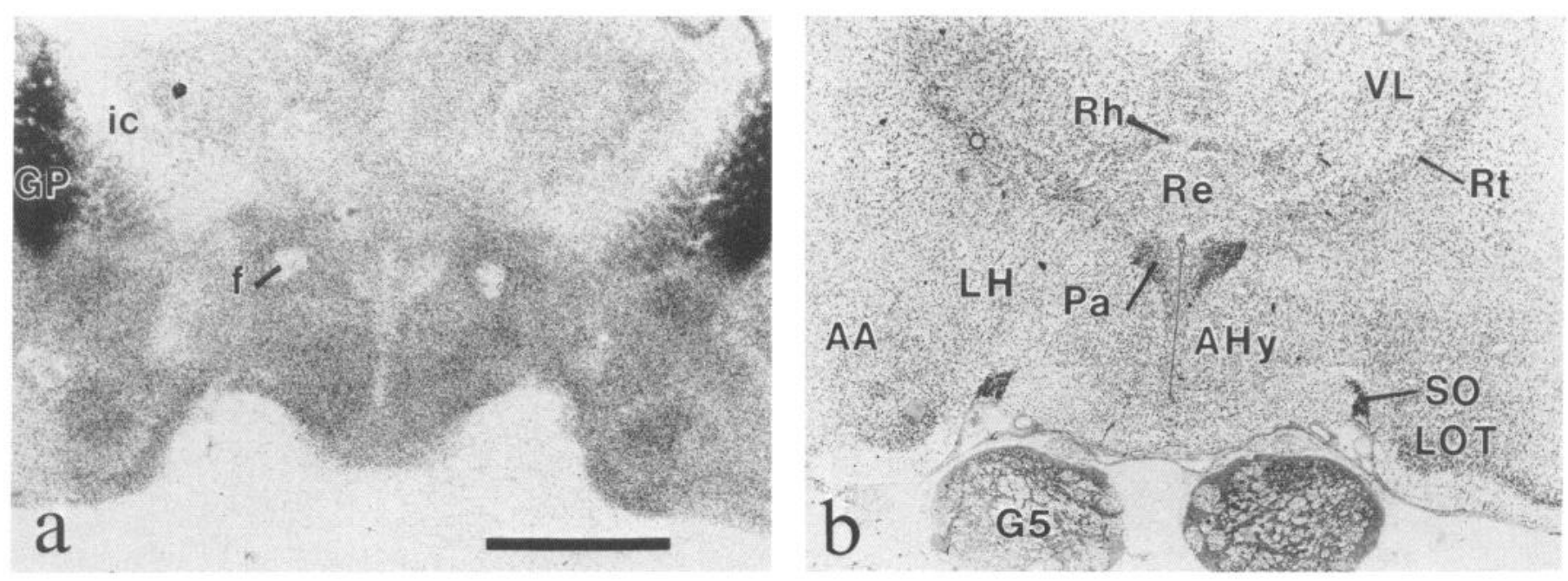

Figure 10. Autoradiography of $10 \mathrm{~nm}{ }^{3} \mathrm{H}-\mathrm{CP} 55,940$ binding in the anterior hypothalamus and adjacent structures. See Appendix for abbreviations. Scale bar, $2 \mathrm{~mm}$ for $a$ and $b$.

very dense binding, as did the CA3 region of Ammon's horn. Dense binding filled with CA1 region and subiculum. Within the CA fields, the highest levels of binding were in the stratum lacunosum moleculare and in narrow bands flanking the pyramidal cell layer. The granule cell layer of the dentate gyrus had sparse binding, and the hilus had moderate levels (Fig. 9).

Parahippocampal areas showed heterogeneity of binding. The subiculum had dense binding, the presubiculum had selectively sparse binding, and the parasubiculum had moderate binding (Figs. 6, 7a-c). The presubiculum had a bilaminar pattern of labeling, with peaks in the most superficial and deep layers (Fig. $6 l$ ).

The hippocampal binding patterns described above were more prominent in the dorsal than in the ventral hippocampus. In ventral hippocampus, the overall density was slightly lower, and the variability across areas and layers was reduced. Especially noticeable in this regard was the dense labeling found only in the dorsal and not in the ventral subiculum (Figs. $6 l, 7 a-c$ ).

Forebrain, basal areas. The septum and basal forebrain had moderate binding throughout. Within the septum, the vertical limb of the nucleus of the diagonal band, medial septum, and intermediate nucleus of the lateral septum were elevated (Figs. $6 e, 7 b, c)$. The lateral and postcommissural septal nuclei and the basal nucleus of the horizontal limb of the diagonal band were relatively lower.

The amygdala had sparse binding rather evenly distributed throughout. The medial nucleus showed the lowest level (Figs. $6 h, i ; 7 c)$. The nucleus of the lateral olfactory tract showed a moderate level (Fig. 10). The bed nucleus of the stria terminalis had sparse binding (Figs. $6 f, 7 b$ ), and the stria terminalis itself showed a discretely localized external rim of elevated binding (Figs. $6 h, i ; 9 ; 11 a$ ).

Basal ganglia. The densest binding in the entire rat brain was localized to the outflow nuclei of the basal ganglia, namely, the globus pallidus, entopeduncular nucleus, and substantia nigra pars reticulata (Fig. $6 f-l$ ). Binding in the globus pallidus and the substantia nigra pars reticulata was denser laterally than medially (Fig. $6 d-g, j ; 7 b ; 11 e$ ). The white matter corresponding to the location of the descending striatonigral pathway was also densely labeled (Figs. 3c, 6i, 11a-d). Binding in the caudateputamen showed a pronounced lateral-to-medial gradient of density; the dorsolateral striatum had very dense binding, and the ventromedial striatum, including the nucleus accumbens, had moderate binding (Figs. $6 d-g, 7 b$ ). Binding elsewhere in the basal ganglia was sparse. The ventral pallidum (Fig. 7a), subthalamic nucleus (Fig. 11a), ventral tegmental area, and subsantia nigra pars compacta (Fig. 11e) had sparse levels of binding.

Diencephalon, thalamus. The thalamus overall had sparse binding. Small density variations formed patterns that correlated with cytoarchitecture (Figs. $6 g-i, 7,10$ ). Binding in the reticular, intralaminar, and medial habenular nuclei was relatively lower than in other parts of the thalamus, and binding in the medial portion of the lateral habenula was relatively higher (Figs. 6i, 9).

Diencephalon, hypothalamus. The hypothalamus had sparse binding that was slightly elevated over levels in the thalamus. Within the hypothalamus, several nuclei were selectively receptor sparse, notably, the suprachiasmatic (Fig. $6 f$ ), supraoptic (Fig. 10), paraventricular (Figs. 6g, 10), ventromedial (Fig. 6h,i), and arcuate nuclei (Figs. $6 h, 11 a$ ) and the median eminence (Fig. $6 h, i$ ) and infundibulum (Fig. 11a). Slightly elevated binding formed a rim around the ventromedial nucleus (Fig. $6 i$ ). The mammillary nuclei showed heterogeneity of binding-the lateral mammillary nucleus was selectively receptor sparse, and the medial part of the medial mammillary nucleus was relatively receptor enriched (Fig. 11c). The posterior hypothalamus, continuing caudally along the ventricle into the central gray region, was also relatively receptor enriched (Fig. 11).

Midbrain and hindbrain. The brain stem had sparse to very sparse binding throughout. Nevertheless, considerable heterogeneity occurred in patterns that correlated with cytoarchitecture. In the mesencephalon, the lateral subnucleus of the interpeduncular nucleus had moderate binding (Fig. $6 l$ ). Slightly lower levels were found in the central gray and intermediate gray layer of the superior colliculus. The oculomotor and red nuclei had very sparse labeling, and the ventral tegmental areas, substantia nigra pars compacta, median raphe, remaining superior colliculus, pons, and reticular formation had generally sparse binding (Figs. $6 j-l, 11 e$ ). The inferior colliculus had very sparse binding, especially in its central portion (Fig. $6 \mathrm{~m}$ ).

The hindbrain also had sparse to very sparse binding, with a 

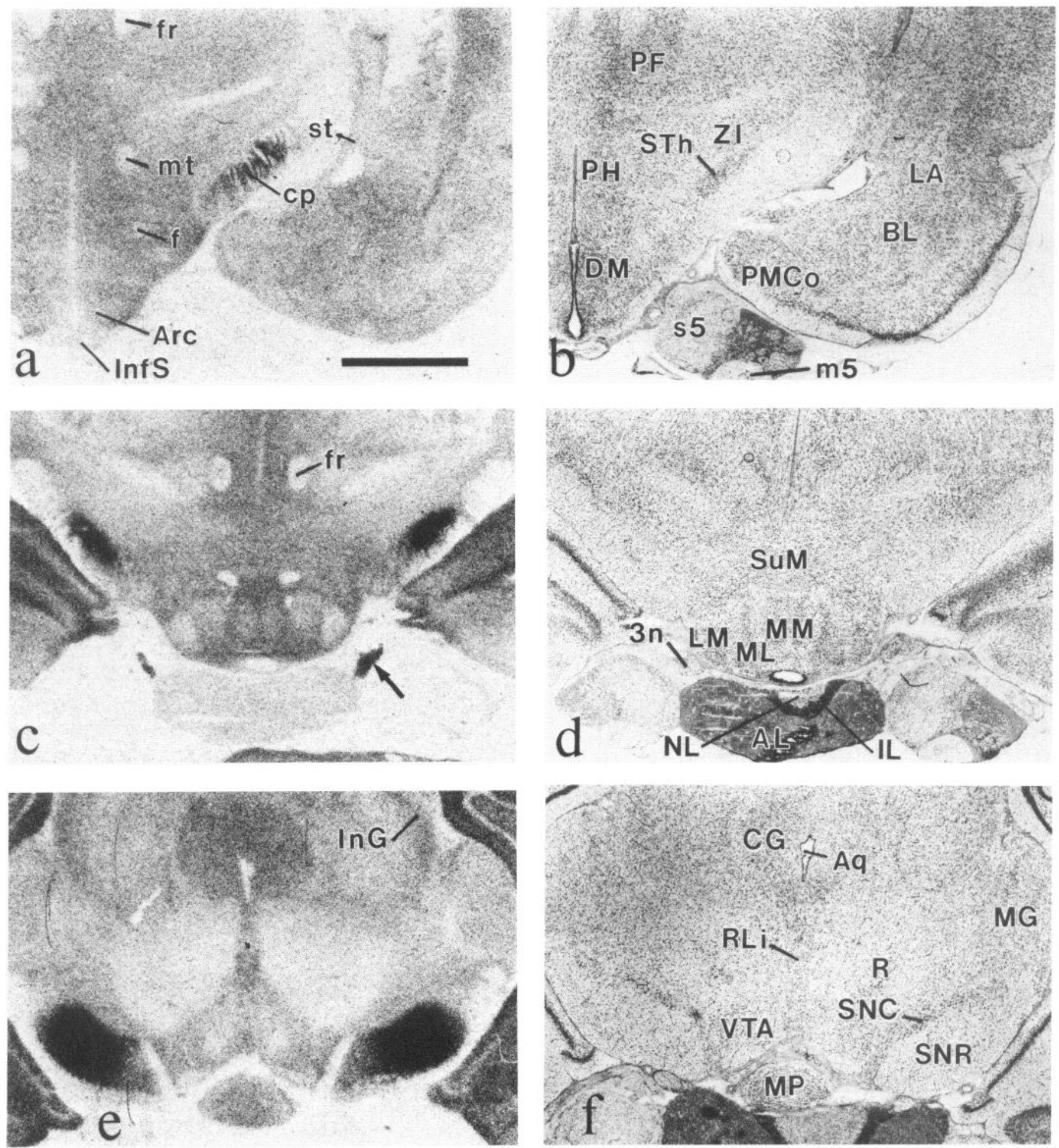

Figure 11. Autoradiography of $10 \mathrm{nM}{ }^{3} \mathrm{H}-\mathrm{CP} 55,940$ binding in the ventral diencephalon and ventral mesencephalon, emphasizing the patterns of labeling in the striatonigral pathway and region of the substantia nigra. Also shown are the pituitary and trigeminal nerve and ganglion. Arrow in $c$ points to connective tissue (see text). See Appendix for abbreviations. Scale bar, $2 \mathrm{~mm}$ for $a-f$.

few notable exceptions. The pontine reticular formation showed very sparse labeling, and the nuclei of the isthmus region showed slightly elevated levels (Figs. $6 n, 12 a$ ). The parabrachial nucleus, especially the dorsal part, had moderate levels of binding. More caudally, the other area showing moderate binding was the nucleus of the solitary tract, which was denser in the caudal and commissural portions (Figs. $7 c, 13 c$ ) than in the rostral portions (Figs. 7c, 13a). The area postrema had sparse labeling (Fig. 13c). Other areas with relatively elevated but still sparse binding were the dorsal (Fig. 13a) and ventral cochlear nuclei (Figs. 6o, 7c), hypoglossal nucleus, dorsal motor nucleus of the vagus (Fig. $13 c$ ), and inferior olive (Figs. $6 p, 13 c$ ). Very sparse labeling was 

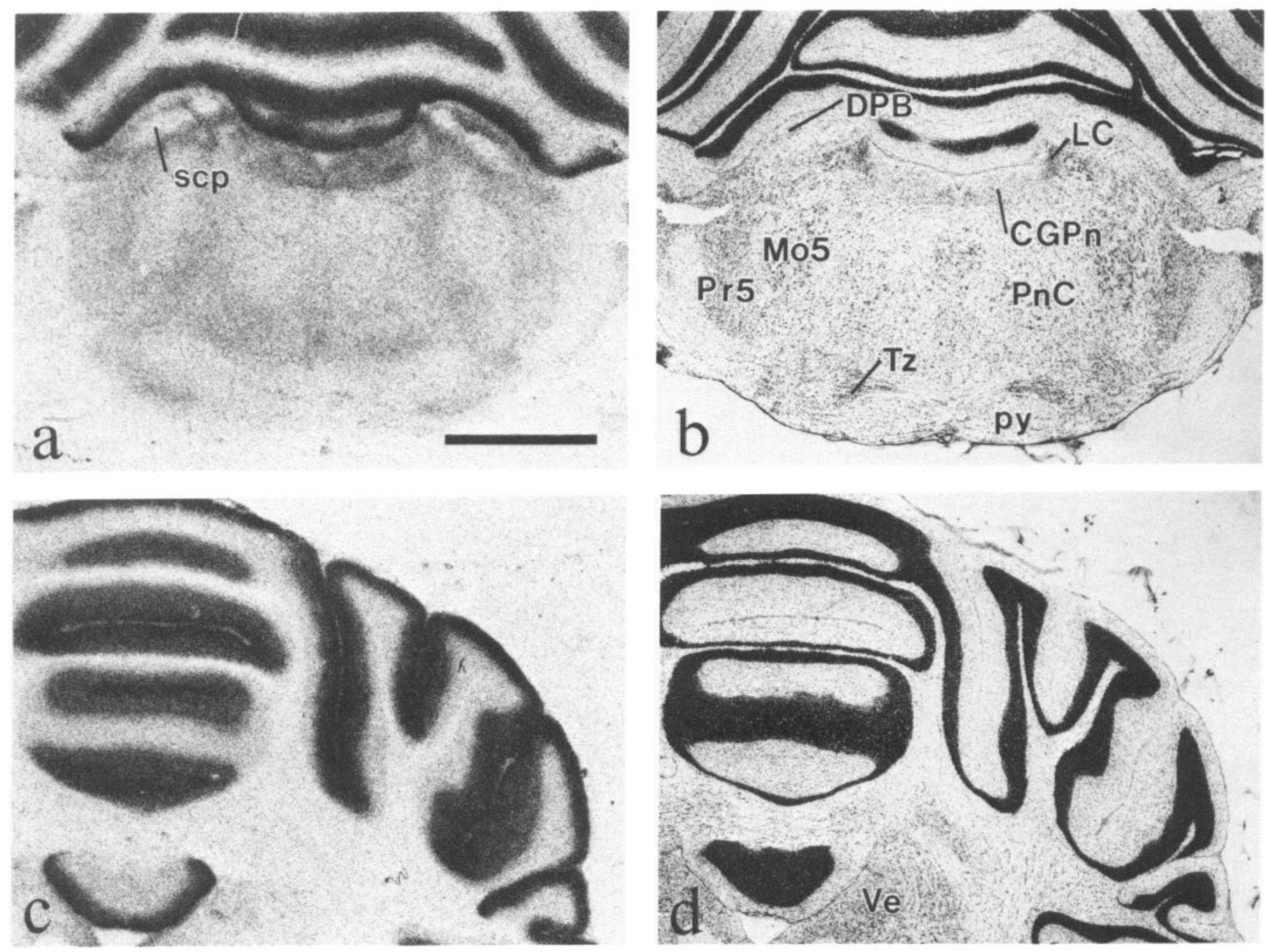

Figure 12. Autoradiography of $10 \mathrm{nM}^{3} \mathrm{H}-\mathrm{CP} 55,940$ binding in the isthmus region $(a, b)$ and cerebellar cortex (c,d). See Appendix for abbreviations. Scale bar, $2 \mathrm{~mm}$ for $a-d$.

measured in the parvocellular reticular formation and in sensory and motor nuclei of the brain stem, notably, the vestibular, trigeminal, facial, ambiguus, trapezoid, cuneate, and gracile nuclei (Figs. $6 o, p ; 12 ; 13$ ). The trigeminal ganglion and nerve had very sparse binding (Figs. 10,11), though an unidentified portion of its connective tissue occasionally showed moderately dense specific binding (Fig. 11c).

Cerebellum. The molecular layer of the cerebellar cortex had very dense labeling throughout all portions of the cerebellum (Figs. $6 n-p ; 7 a, b ; 12 ; 13$ ). In contrast, the cerebellar granular layer had very sparse binding, and the deep cerebellar nuclei had the lowest level of binding found in the brain (Figs. $6 o$; $7 a, b ; 12 c)$.

Spinal cord. Patterns of labeling were similar at all levels of the spinal cord, represented by a cervical level in Figure 14. The ventral horn showed very sparse binding. Binding was slightly higher in the substantia gelatinosa and lamina X.

\section{Discussion}

\section{Binding characteristics}

The present and recent studies (Devane et al., 1988; Herkenham et al., 1990) using ${ }^{3} \mathrm{H}-\mathrm{CP} 55,940$ as a ligand have revealed for the first time evidence for a unique cannabinoid receptor that meets the criteria of saturability, specificity, pharmacological significance, and unique pattern of localization in brain. As discussed elsewhere (Devane et al., 1988; Herkenham et al., 1990), earlier attempts to characterize the cannabinoid receptor by the use of ${ }^{3} \mathrm{H}-\Delta^{8}-\mathrm{THC}$ (Harris et al., 1978) or ${ }^{3} \mathrm{H}-\Delta^{9}-\mathrm{THC}$ (Roth and Williams, 1979) were unsuccessful because these cannabinoids bind with low affinity and have low specific activities. Technical problems associated with ligand hydrophobia were also encountered. Use of a water-soluble cannabinoid ligand, ${ }^{3} \mathrm{H}-5^{\prime}$-trimethylammonium $\Delta^{8}$-THC $\left({ }^{3} \mathrm{H}\right.$-TMA), was attempted (Nye et al., 1985). However, it does not act like a cannabinoid in most animal tests, binds with a relatively homogeneous distribution in brain, and has low affinity for the presently described receptor (Herkenham et al., 1990). A diverse series of cannabinoids displaced ${ }^{3} \mathrm{H}$-TMA binding but without correlation to known biological activities (Nye et al., 1985). The binding site for this compound was described as a myelin basic protein of unknown function (Nye et al., 1988, 1989). Thus, the ${ }^{3} \mathrm{H}-\mathrm{TMA}$ binding site is clearly different from the presently described cannabinoid receptor.

Previous characterization of ${ }^{3} \mathrm{H}-\mathrm{CP} 55,940$ binding to slidemounted sections of rat brain showed that the binding has high affinity (apparent $\left.K_{d}=15 \mathrm{nM}\right)$, high capacity $\left(B_{\max }=900 \mathrm{fmol} /\right.$ 

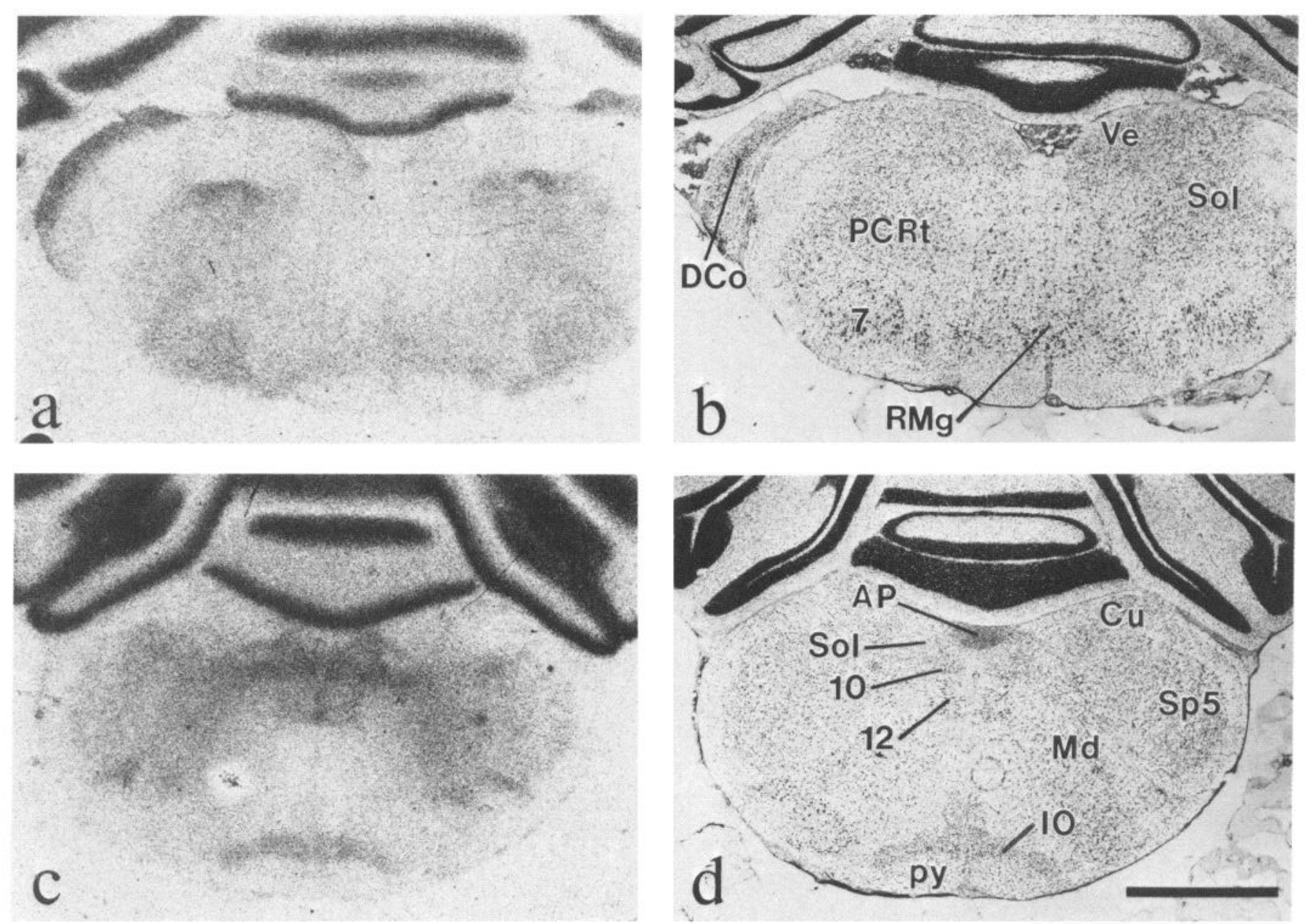

Figure 13. Autoradiography of $10 \mathrm{nM}{ }^{3} \mathrm{H}-\mathrm{CP} 55,940$ binding in the medulla at rostral $(a, b)$ and caudal $(c, d)$ levels of the nucleus of the solitary tract. See Appendix for abbreviations. Scale bar, $2 \mathrm{~mm}$ for $a-d$.

$\mathrm{mg}$ protein in whole-brain "sausage" sections), and is competitively and selectively inhibited by cannabinoid drugs with relative potencies that correlate highly with their potencies in most well-characterized tests of cannabinoid pharmacology and physiology (Herkenham et al., 1990). In this study, the association and dissociation experiments confirm the high affinity and demonstrate that ${ }^{3} \mathrm{H}-\mathrm{CP} 55,940$ binding is reversible. They also show that binding is slow to reach equilibrium. Whether this reflects a physicochemical property of cannabinoids or something about the molecular nature of the interaction of the drug with the receptor is not known. The rationale behind performing the experiment for autoradiographic analysis was based on the fact that the autoradiographic image produced by tritium emissions comes from the topmost few micrometers of tissue (Rogers, 1979). Comparing rates of association by scintillation counts versus autoradiography addresses the possibility that slow penetration of ligand into the tissue is responsible for the slow rate of association. Dissociation might be more difficult to interpret, as radiolabel would elute out of the sections by passing from deep through superficial parts. In fact, the rate of association at the surface (autoradiography) was about 3-fold faster than throughout the section (scintillation counting), and this feature was the major determinant of the higher affinity determined by autoradiography ( $K_{d}=5.2$ vs. $\left.21 \mathrm{nM}\right)$. However, the general similarity of results obtained by the 2 methods suggests that penetration is not a major determinant of time to reach equilibrium.

Another possibility for the slow time to reach equilibrium is that cannabinoids must dissociate from the carrier (BSA) in order to associate with the receptor. Arguing against this process as a contributor to the slow rate of association is the finding that the association rate in incubation solution with $1 \%$ BSA was similar to that with $5 \%$ BSA (Herkenham, 1991). In addition, Devane et al. (1988), using a different assay and no BSA, found that equilibrium was reached after incubation for $1 \mathrm{hr}$ at $30^{\circ} \mathrm{C}$. Future work with ligand binding in vivo may shed light on physiological rate-determining mechanisms, and studies of the location of the drug recognition site on the receptor molecule may provide clues at the molecular level.

Extending our previous findings (Herkenham et al., 1990), we show that the inhibition of binding of $10 \mathrm{nM}{ }^{3} \mathrm{H}-\mathrm{CP} 55,940$ by nonhydrolyzable analogs of guanine nucleotides is dose dependent (Fig. 3). The magnitude of inhibition of binding of $10 \mathrm{nM}$ ${ }^{3} \mathrm{H}-\mathrm{CP} 55,940$ by GMP-PNP suggests that the low-affinity state in this assay has a very low affinity, though that $K_{d}$ is unknown from these data. The model of G-protein interactions with a receptor-agonist ligand complex proposed by Gilman (1987) holds that the receptor is in a low-affinity state when associated 
with a G-protein in the presence of either GTP or GDP. GDP is rapidly replaced by GTP if it is available, which maximally promotes the low-affinity state. Thus, the present data are consistent with this model because both GTP and GDP inhibit the binding, but GTP is about 10 -fold more potent. The lack of potencies of GMP and AMP-PNP supports the model of G-protein interaction and shows that the binding is not coupled to other nucleotide-utilizing proteins.

The G-protein-coupled adenylate cyclase second-messenger system, mapped by ${ }^{3} \mathrm{H}$-forskolin binding (Worley et al., 1986), is enriched in brain areas that comprise a subset of areas rich in cannabinoid receptors. This anatomical correspondence, the very high abundance of cannabinoid receptors, and the profound inhibition of binding by guanine nucleotides suggest that cannabinoid receptors are closely associated with this second-messenger system. Functional studies lend direct support for this hypothesis. The relative potencies in vivo for inhibition of adenylate cyclase by several cannabinoids in cell lines (Howlett, 1987; Howlett et al., 1988) correlates with their potencies in vitro. Recently, Matsuda et al. (1990) have used the adenylate cyclase assay and structure-activity relationships to show that a cloned G-protein-coupled receptor is a cannabinoid receptor in transfected cells. The similarity of rat brain distribution of the radiolabeled mRNA probe for the cloned receptor with the presently described cannabinoid receptor distribution further suggests that they are the same entity.

The competition curves (Fig. 4) for several synthetic cannabinoids can be compared with similar kinds of data for other cannabinoids (Herkenham et al., 1990). For all cannabinoids tested, the derived potencies $\left(\mathrm{IC}_{50} \mathrm{~s}\right.$ or $\left.K_{i} \mathrm{~s}\right)$ correlate very closely with relative potencies in behavioral tests (Howlett et al., 1988). Notably, ( \pm )-CP42,096 and $N$-methyllevonantradol are equipotent and about 10 -fold more potent than (-)-CP47,497 and (+)-CP47,497 in both the binding assay and tests of analgesia in mice (Johnson and Melvin, 1986; Howlett et al., 1988). As noted previously (Herkenham et al., 1990), the enantioselectivity of the (-) and (+) forms of CP55,244 is striking-their potencies differ by more than 10,000 -fold in vitro, a separation predicted by the more rigid structure of the molecule (Fig. 1; Johnson and Melvin, 1986) and by potencies in vivo (Johnson and Melvin, 1986; Little et al., 1988). In contrast, the less rigid bicyclic enantiomers of CP47,497 show little enantioselectivity in both the binding and the behavioral assays (Howlett et al., 1988). These results suggest that enantioselectivity of these compounds is, in large part, determined by the precise stereochemical orientation of moieties in and surrounding the spatial domain of the pyran ring (B-ring) of $\Delta^{9}$-THC, a region proposed to consist of inner lipophilic and outer hydrophilic zones that interact with the receptor cavity (Howlett et al., 1988).

\section{Functional anatomy}

Motor systems. The most striking aspect of cannabinoid receptor distribution in rat brain is the dense localization in discrete parts of the basal ganglia and cerebellum. The basal ganglia and related subcortical structures comprise the extrapyramidal motor system, and this system, together with the cerebellum and its connected structures, subserves many forms of movement control. Information flow in the basal ganglia follows circuitry through the striatum and its efferent targets, the globus pallidus, entopeduncular nucleus, and substantia nigra. Very dense cannabinoid receptors selectively occupy the full extents of these outflow nuclei. Receptors are dense also in the location of the
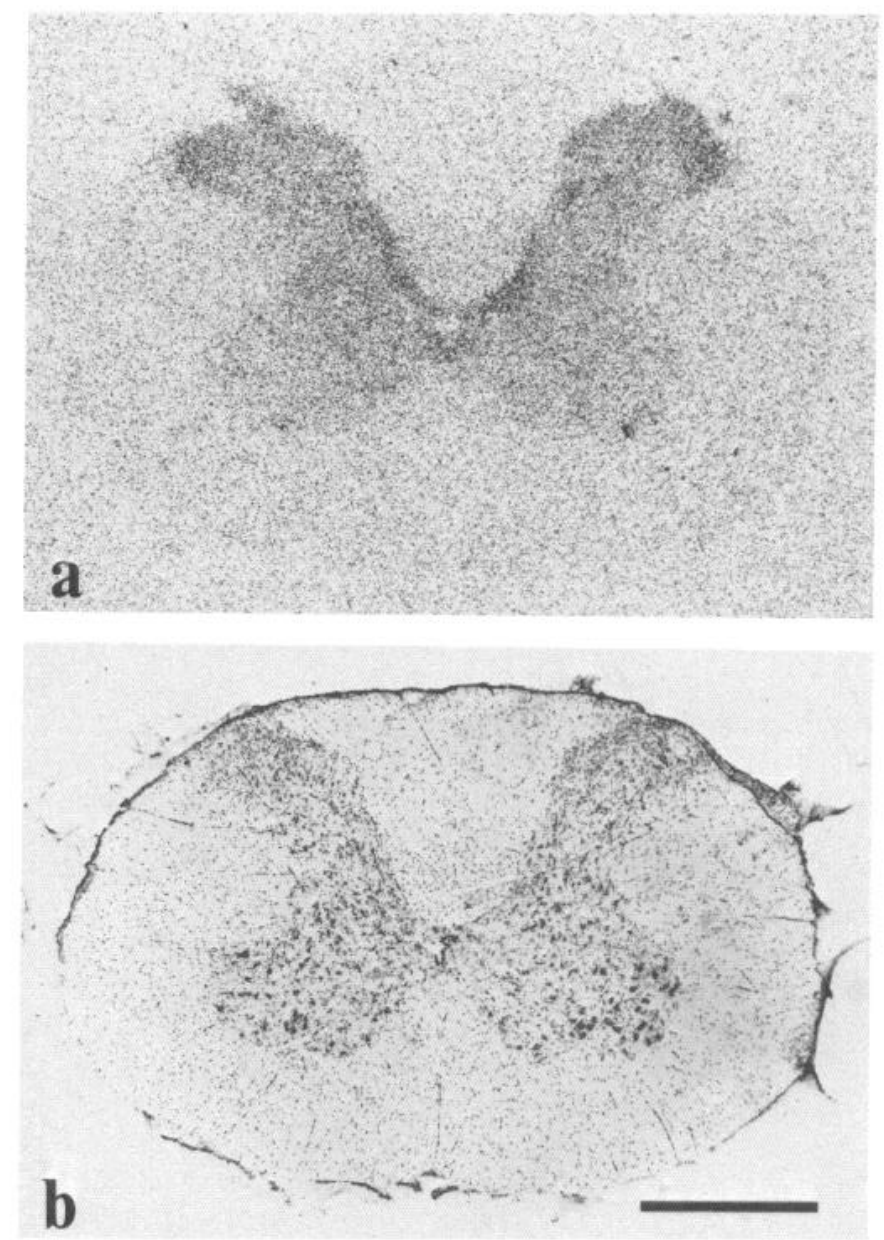

Figure 14. Autoradiography of $10 \mathrm{~nm}{ }^{3} \mathrm{H}-\mathrm{CP} 55,940$ binding in the cervical spinal cord $(a)$. Cellular laminae are visible in the corresponding Nissl-stained section $(b)$. Scale bar, $1 \mathrm{~mm}$ for $a$ and $b$.

striatal efferent pathway, suggesting that this entire array of dense labeling may represent receptors on axons and terminals of striatofugal neurons. Indeed, such "presynaptic" localization of cannabinoid receptors was confirmed in studies showing the loss of receptors in the striatum, pallidum, and nigra following destruction of striatal neurons with ibotenic acid (Herkenham et al., 1989).

Outside the domain of the striatal efferent neuron, cannabinoid receptors in the extrapyramidal motor system are sparsely distributed. Notably, very few receptors are found in the nuclei that receive pallidal and nigral projections (subthalamic nucleus, ventromedial thalamus). Of the striatal afferent sources, only the cerebral cortex has moderately dense receptors, whereas the afferent thalamic and nigral dopamine neurons are receptor sparse.

A striking feature of cannabinoid receptor localization in the basal ganglia is the gradient of binding density in the neostriatum such that the dorsolateral sector of the head of the caudateputamen is greatly enriched in receptors, and the ventromedial sector has only moderate levels. The area of receptor enrichment closely coincides with the sensorimotor portion of the striatum that receives afferent inputs from the primary sensory and primary motor cortex in the rat (McGeorge and Faull, 1989). The densest part of the enriched region is rather ventral within this dorsolateral district (Fig. 6e), coinciding with the recipient zone of projections from the primary motor cortex (Kelley et al., 
1982). Given the topography of striatal efferent projections, it is also noteworthy that the receptor-rich lateral striatum is connected with the relatively receptor-rich lateral globus pallidus and substantia nigra pars reticulata.

Examination of patterns of cannabinoid receptor binding in other mammals (Herkenham et al., 1990) reveals that the selective enrichment in the 3 outflow nuclei of the basal ganglia is a common feature (though in monkeys and humans, the external segment of the globus pallidus is typically lower in receptor density than the internal segment). The lateral-to-medial striatal gradient is unique to the rat among the species examined. No evidence of compartmental heterogeneity of striatal binding has been found in the rat or any of the other species examined thus far.

Another noteworthy feature of reccptor patterns is the low binding in the ventral pallidum. Several cytoarchitectonic and neurochemical markers reveal a continuity of the globus pallidus proper with the ventral pallidum (Switzer et al., 1982), but cannabinoid receptors clearly distinguish the 2 sectors. The ventral pallidum receives inputs from the ventral striatum, including the nucleus accumbens. By its connectivity, the ventral pallidum has been assuciated with the limbic system, and it may be part of the neural systems mediating rewarding drug selfadministration in rats (Hubner and Koob, 1990). Thus, in the rat at least, cannabinoid receptors distinguish the 2 major functional compartments of the corpus striatum: They are dense in the sensorimotor compartments and relatively sparse in the ventromedial, "limbic" domain (Kelley et al. 1982).

The basal ganglia and the cerebellum are likely sites for mediation of cannabinoid actions affecting movement. Inhibition of movement is typical, though a hyperreactivity to stimuli has been noted in mice (Dewey, 1986). A separation of cannabinoid effects has been noted such that $\Delta^{9}$-THC, which has relatively high affinity for binding to the cannabinoid receptor and shows psychoactivity, has both a stimulatory and an inhibitory component, whereas cannabinol and cannabidiol, which have very low affinity (Herkenham et al., 1990) and which do not show psychoaclivity, have only depressant actions on motor function (Dewey, 1986). Cannabinoid effects on movement are also dose dependent. At low doses, cannabinoids decrease spontaneous activity, and at higher doses, they elicit catalepsy in mice (Little et al., 1988). (Cataleptic mice are conscious and remain for long periods of time in fixed postures with normal muscle tone; Pertwee and Greentree, 1988).

Basal ganglia involvement in the motor effects is suggested by several research findings. $\Delta^{9}$-THC injected directly into the caudate causes catalepsy in rats, though $\Delta^{9}$-THC injected into the globus pallidus does not (Gough and Olley, 1978). $\Delta^{9}$-THC injected into the nucleus accumbens increases spontaneous activity at low doses and has no effect at high doses (Conti and Musty, 1984). Neurochemical blockade of the striatal dopamine system, by reserpine or haloperidol administration, potentiates $\Delta^{y}$-THC-induced catalepsy (Moss et al., 1984).

Rapid, profound, and prolonged tolerance to a number of $\Delta^{9}$ THC effects has been documented (Dewey, 1986). Perhaps this is why movement depression (other than sleepiness and lethargy) is typically not observed experimentally in human subjects, most of whom have had prior history of marijuana use (Manno et al., 1970; Jones and Benowitz, 1976).

In the cerebellum, cannabinoid receptors homogeneously and densely fill the molecular layer in all lobes of the cerebellar cortex, without any obvious regional variations in density. Work in progress with strains of mice with genetic defects leading to cerebellar pathology indicates that dense receptors in the molecular layer are localized to axons of cerebellar granule cells (M. Herkenham, B. Groen, A. Lynn, B. deCosta, and E. Richfield, unpublished observations). Thus, analogous to the arrangement found in the basal ganglia, a single neuronal element in the cerebellum may contain the dense receptors, whereas connected structures have very sparse receptors (deep cerebellar nuclei, red nucleus, ventrolateral thalamus, pons, inferior olive, and other brain-stem nuclei).

Receptors in the cerebellum are candidates for sites mediating ataxia produced by cannabinoids. We have previously suggested cerebellar mediation of the static ataxia elicited by cannabinoids in dogs on the basis of elevated receptor density in the cerebellum in this species relative to other species, notably human (Herkenham et al., 1990).

The cerebellum may have roles other than control of movement. It is now well known that the cerebellar molecular layer is enriched in receptors for numerous types of neuropeptides, monoamines, and other transmitters, often in the absence of evidence for neuronal inputs containing these substances, suggesting parasynaptic, or hormonal, modulation of function (Herkenham, 1987). Other brain areas with similar enrichments in numerous kinds of neuromodulator receptors are typically found in the domain of the limbic system or forebrain circuits mediating complex, multimodal information flow. Cerebellar pathology has been associated with schizophrenia (Weinberger et al., 1980) and autism (Courchesne et al., 1988). Perhaps cerebellar cannabinoid receptors fall in a class of receptors that play some role in cerebellar processing of cognitive information.

Cerebral cortex. A major territory of dense receptor accumulation is the cerebral cortex. Cannabinoid receptors are moderately dense throughout the cortex and show greater binding in the frontal cortex than elsewhere, and somewhat lower levels in more ventrally situated cortex, including the auditory, piriform, and entorhinal areas. In most areas, the labeling is bilaminar, with peaks in layers I and VI. In areas with a well-defined granular layer IV, a noticeable trough of binding overlies the granular portions. In the prelimbic and primary motor and somatosensory areas, a third minor peak is measured in layers III and $\mathrm{Va}$, respectively. Densitometry reveals that the density changes are gradual across layers (Fig. 8). Though many other families of receptors have homogeneous, dense, and bilaminar distributions, they do not show this appearance of steady density transition spanning layers. The distributions suggest that cannabinoids might have a very global and undifferentiated effect on cortical neuronal excitability, exerting influences on pyramidal neurons in all layers by occupying receptors on distal dendrites in the upper layers and basal dendrites in deeper layers. Modulation of outflow is suggested by the dense location of receptors in layer VI, which contains neurons that have long projections to brain stem and spinal cord.

Cannabinoid effects on cortical electrophysiology and seizure susceptibility can be biphasic, with low doses of $\Delta^{9}$-THC producing excitation and higher doses producing depression of electrical activity (Turkanis and Karler, 1981a,b, 1987). Cannabidiol shows only depressant actions at all doses (Turkanis and Karler, 1981a). Several animal models of seizure susceptibility have provided sufficient data to suggest that some cannabinoid actions follow structure-activity relationships, and thus may be receptor mediated, and some do not. In rats, low doses of $\Delta^{9}$ THC and $11-\mathrm{OH}-\Delta^{9}$-THC evoke focal cortical epileptic bursts 
in a dose-dependent fashion, but cannabidiol has no effect even at high doses (Turkanis and Karler, 1982). In one rabbit strain, cannabinoids elicit convulsions at low doses and with relative potencies predicted by the structure-activity relationship (Consroe et al., 1982).

The biphasic nature of cannabinoid effects on cortical electrophysiology has a parallel in cortical metabolism. A recent autoradiographic study has shown that $\Delta^{9}$-THC produces dosedependent biphasic increases and decreases in 2-deoxyglucose uptake in rat brains (Margulies and Hammer, 1991). Similar biphasic effects are achieved with CP55,940 administered at lower doses (Margulies and Hammer, 1990).

The widespread and dense distribution of cannabinoid receptors in the cerebral cortex is similar to the cortical distribution of benzodiazepine receptors. Colocalization on cortical neurons may provide a mechanism for cannabinoid potentiation of the anticonvulsant actions of benzodiazepines. A series of cannabinoids, with potencies that closely follow analgesic activity (Koe et al., 1985) and $K_{i}$ s at the receptor (Fig. 4; Herkenham et al., 1990), potentiate the effect of diazepam on elevation of threshold for convulsions caused by pentylenetetrazol in mice (Koe et al., 1985). The same cannabinoids stereospecifically inhibit in vivo binding of ${ }^{3} \mathrm{H}$-flunitrazepam binding in mouse brain at doses predicted by the structure-activity relationship (Koe et al., 1985).

It is likely that cortically localized receptors mediate at least some of the psychoactive effects of cannabinoids. Biphasic perceptual and psychic changes occur with acute marijuana administration: The initial euphoria or "high" is followed by drowsiness. Time sense is altered, subjects have difficulty in concentrating, and dreamlike states are prominent (Hollister, 1986). The marijuana "high" is described in terms that include pleasant, relaxed, dizzy, flight of ideas, hungry, introspective, and numbness in the body (Hollister and Gillespie, 1974). Levonantradol (CP50,556-1) taken orally produces drowsiness, sedation, thought disturbances, and dizziness, with dysphoria more likely than euphoria (Johnson and Melvin, 1986). Dysphoria has been reported also with $\Delta^{9}-\mathrm{THC}$ administered orally in clinical settings (Sweet et al., 1981).

Hippocampus. Cannabinoid receptors are dense in the hippocampus, with highest levels localized to the dentate gyrus molecular layer and the CA3 fields. The cellular elements that contain the receptors are not known at present, though subpopulations of dentate granule cells have been shown to express cannabinoid receptor mRNA (Matsuda et al., 1990). Additional information would be helpful to promote understanding of how cannabinoids affect hippocampal functioning. $\Delta^{9}$-THC effects on hippocampal excitability in vivo (Weis el al., 1982) and in vitro are biphasic (Foy et al., 1982; Kujtan et al., 1983), with low doses enhancing orthodromic field potentials and high doses depressing evoked responses. Consistent but contradictory effects on recurrent inhibition suggest involvement of intrinsic GABA neurons (Weisz et al., 1982; Kujtan et al., 1983).

In human studies, $\Delta^{9}$-THC disrupts selective aspects of shortterm memory tasks analogous to deficits measured after damage to the hippocampus and associated cortical areas (Miller and Braconnier, 1983; Aigner, 1988). The hippocampus is pivotally involved with coding of sensory information (Eichenbaum and Cohen, 1988) and storage of memories (Thompson et al., 1983). In animal studies, $\Delta^{9}$-THC but not cannabidiol disrupts performance in tasks that require vigilance or estimating passage of time (Schulze et al., 1988; Deadwyler et al., 1990). $\Delta^{9}$-THC produces deficits in delayed matching-to-sample tasks as do hippocampal lesions (Deadwyler et al., 1990). $\Delta^{y}$-THC impairs tone discrimination in the same dose ranges that suppress rat dentate gyrus granule cell responses to sensory (auditory) information in the perforant path (Campbell et al., 1986a,b).

Olfactory structures. Labeling in the main olfactory bulb is highly confined to the innermost layers, a pattern not seen with other receptors, which are typically localized to the external plexiform layer. This discrete localization resembles the pattern of termination of centrifugal projections from the anterior olfactory nuclei (Broadwell, 1975). Axons of the crossed portion of this projection pass in the anterior limb of the anterior commissure, which is selectively labeled with cannabinoid receptors. Another target of anterior olfactory nuclei projections is layer Ib of rostral parts of the primary olfactory cortex, which also shows selectively elevated cannabinoid binding in the same rostral portion (Broadwell, 1975). Thus, it is possible that part of the pattern of labeling in the olfactory system can be attributed to receptors distributed throughout the axons and terminals of neurons of the anterior olfactory nucleus, a hypothesis that can be tested experimentally.

Hypothalamus and pituitary. Cannabinoid receptors are sparsely and rather homogeneously distributed in the hypothalamus, with lowest densities in the magnocellular nuclei. In the pituitary, very sparse receptors are confined to the neural lobe. Cannabinoid effects on endocrine function do not show appropriate structure-activity relationships, suggesting that they are not mediated by the cannabinoid receptor (Pertwee, 1985). $\Delta^{9}$-THC elevates plasma corticosterone and ACTH levels in rats (Pertwee, 1985), and this effect disappears when the lypothalamus is deafferented but otherwise left responsive and intact with the pituitary (Puder et al., 1982). A possible central site of action is the hippocampus, where $\triangle^{4}$-THC has been shown to inhibit corticosterone uptake (Drew and Slagel, 1973) and compete with moderate affinity $\left(\mathrm{IC}_{5 i}\right.$ of $250 \mathrm{~nm}$ ) in vitro for ${ }^{3} \mathrm{H}$ dexamethasone binding to glucocorticoid receptors (Eldridge et al., 1990).

Cannabinoids produce hypothermia in mice in a dose-dependent and enantioselective fashion, with potencies consistent with the structure-activity relationship (Little et al., 1988). $\Delta^{9}$ THC reduces body temperature following intraventricular injections or injection directly into the preoptic area (Fitton and Pertwee, 1982; Martin, 1986), suggesting mediation by hypothalamic cannabinoid receptors.

Lower brain stem and spinal cord. Cannabinoid receptors are rather sparsely distributed throughout the brain stem and spinal cord. However, systemically administered cannabinoids do elicit certain auionomic responses, and, to the extent that they are receptor mediated, some of the regional variations in density may be relevant.

The lethal dose of acutely administered $\Delta^{y}$-THC in animals is approximately 100-1000-fold greater than the dose that affects spontaneous activity (Harris et al., 1977). With intravenous administration of $\Delta^{8}$-THC in mice, the drop in body temperature and lethality are dose dependent (Yoshimura et al.,1978); both are prevented by warming the animal (Fitton and Pertwee, 1982). Lethality resulting from injected high doses may be also related to nonspecific actions of such a hydrophobic compound (Harris et al., 1977).

There are virtually no reports of fatal cannabis overdose in humans (Harris et al., 1977; Hollister, 1986). The safety is likely due to the paucity of receptors in medullary nuclei that mediate 
vital respiratory (Millhorn and Eldridge, 1986) and cardiovascular functions (Kalia, 1981). Drugs known to depress respiratory and cardiovascular functions (e.g., opiates and benzodiazepines) have high levels of binding in the medulla (Atweh and Kuhar, 1977; Zezula et al., 1988).

$\Delta^{9}$-THC causes tachycardia in humans and bradycardia in animals (Dewey, 1986). In both, it causes a fall in blood pressure. Cannabinoids may modulate noradrenergic sympathetic activity (Vollmer et al., 1974). Such control could occur in the intermediolateral cell column of the thoracic spinal cord or in rostral centers with afferent connections. Nuclei in this circuitry are typically receptor sparse. One candidate for control is the caudal part of the nucleus of the solitary tract, which has moderate binding and sends axons to the intermediolateral cell column (Loewy and Burton, 1978). Receptors in more cephalic centers of the neuraxis might be responsible, which could help to explain why similar distributions across species nevertheless mediate tachycardia in humans and bradycardia in animals.

One of the therapeutic uses of cannabinoids is the treatment of glaucoma (Hollister, 1986). $\Delta^{9}$-THC is known to reduce intraocular pressure, and the effect in experimental animals requires intact noradrenergic sympathetic fibers derived from the superior cervical ganglion, with probably a central as well as ganglionic site of action (Green and Kim, 1976; Green et al., 1977). This response may be receptor mediated because it occurs at relatively low doses intravenously and does not occur when relatively inactive cannabinoids - cannabinol and cannabidiol-are administered (Liu and Dacus, 1987).

Another therapeutic application of cannabinoids, their antiemetic action (Hollister, 1986), is not easily explained by receptor distributions. The emetic reflex centers for chemical stimuli-the area postrema, parvocellular medullary reticular formation (PRF), and visceromotor nuclei (Borison et al., 1981)are all receptor sparse. Possibly, receptors in the nucleus of the solitary tract, which abuts the area postrema, may mediate the effects. Alternatively, the antiemetic actions of dopamine antagonists may suggest much more remote sites of action, perhaps in the basal ganglia (Borison et al., 1981). Forebrain afferents to the PRF include the substantia nigra pars reticulata and central nucleus of amygdala (Mehler, 1983), both elevated in cannabinoid receptors.

The analgesic effects of cannabinoids are, in part at least, mediated by actions at the level of the spinal cord (Gilbert, 1981; Yaksh, 1981). Several cannabinoid drugs have been shown to inhibit spinal reflexive responses to noxious stimuli given to dogs with spinal transections (Gilbert, 1981) and to rats following intrathecal administration (Yaksh, 1981), but data are insufficient to determine a structure-activity profile. Cannabinoid receptors in the spinal cord are sparse but relatively elevated in the dorsal horn where primary afferents carrying noxious inputs terminate. The periaqueductal gray is an additional way station in the pain circuit that has low levels of cannabinoid receptors that are nevertheless elevated over levels in adjacent territories.

\section{Conclusions}

Cannabinoids administcred to both animals and humans clicit characteristic motor, cognitive, analgesic, and autonomic effects that occur at low doses, suggesting that they are mediated by specific receptors in the CNS. Structure-activity relationships generated experimentally show that many of these effects are mediated by the presently identified cannabinoid receptor. Anatomical localization provides likely brain sites of action through which the cannabinoids act. The alteration in motor and cognitive functions elicited by cannabinoids can be understood by the wealth of receptors in the basal ganglia, cerebellum, hippocampus, and cerebral cortex. Therapeutic effects of marijuana smoking on spasticity and ataxia associated with multiple sclerosis (Meinck et al., 1989) may be mediated by receptors in motor areas. Analgesic and autonomic effects of cannabinoids, thought to be promising therapeutically, do not have clear anatomical bases insofar as receptors are generally quite sparse in the brain-stem areas that mediate such effects. However, cannabinoid receptors are quite plentiful throughout the brain, showing greater absolute density than peptide receptors, for example. Furthermore, some brain-stem and spinal cord structures show relative elevations in density that might offer bases for several physiological effects of cannabinoids that hold promise as therapeutic effects. The relative elevations in the nucleus of the solitary tract and the dorsal horn of the spinal cord suggest that these sites mediate cannabinoid effects on autonomic functions and pain thresholds.

\section{Appendix}

\section{List of Abbreviations}

3, oculomotor nucleus

3n, oculomotor nerve

7, facial nucleus

7n, facial nerve

10, dorsal motor nucleus vagus

12, hypoglossal nucleus

AA, antcrior amygdaloid area

ac, anterior commissure

Acb, accumbens nucleus

$\mathrm{ACg}, \quad$ anterior cingulate cortex

AHy, anterior hypothalamic area

$\mathrm{AL}, \quad$ anterior lobe pituitary

alv, alveus

AOB, accessory olfactory bulb

AON, anterior olfactory nucleus

AP, area postrema

APT, anterior pretectal area

Aq, aqueduct

Arc, arcuate hypothalamic nucleus

BL, basolateral amygdaloid nucleus

BST, bed nucleus stria terminalis

CA1 -4 , fields $1-4$ of Ammon's horn

$\mathrm{Cb}, \quad$ cerebellum

$\mathrm{CbN}$ deep cerebellar nucleus

cc, corpus callosum

CC, central canal

$\mathrm{Ce}$ central amygdaloid nucleus

CG, central gray

CGPn, central gray pons

$\mathrm{Cg} 3$, prelimbic cortex

Cnf, cuneiform nucleus

$\mathrm{cp}, \quad$ cerebral peduncle

$\mathrm{CPu}, \quad$ caudate-putamen

$\mathrm{Cu}, \quad$ cuneate nucleus

DCo, dorsal cochlear nucleus

DG, dentate gyrus

DLG, dorsolateral geniculate thalamic nucleus

DM, dorsomedial hypothalamic nucleus

$\mathrm{DPB}, \quad$ dorsal parabrachial nucleus

DR, dorsal raphe nucleus

DTg, dorsal tegmental nucleus

En, endopiriform nucleus

Ent, entorhinal cortex

E/OV, ependyma and subependymal layer and olfactory ventricle

EP, entopeduncular nucleus

EPL, external plexiform layer olfactory bulb

$f$ fornix

fi, fimbria hippocampus 


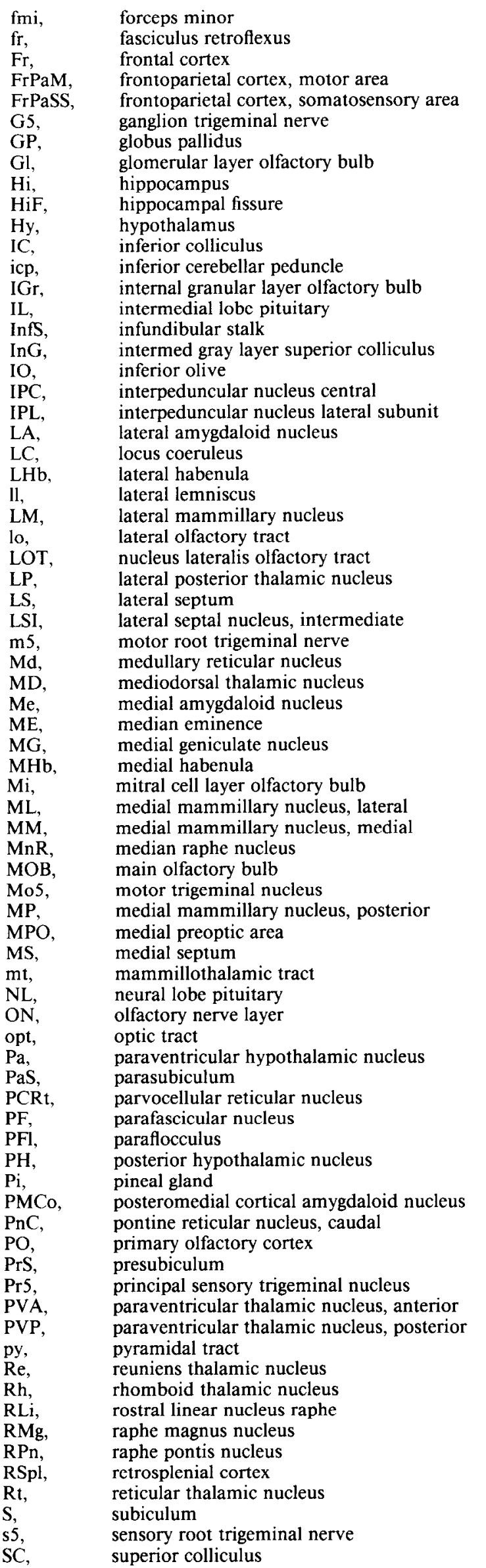

$\begin{array}{ll}\text { SCh, } & \text { suprachiasmatic nucleus } \\ \text { scp, } & \text { superior cerebellar peduncle } \\ \text { SG, } & \text { dentate gyrus stratum granulosum } \\ \text { SI, } & \text { substantia innominata } \\ \text { SLM, } & \text { hippocampal stratum lacunosum-molecular } \\ \text { sm, } & \text { stria medullaris } \\ \text { SNC, } & \text { substantia nigra pars compacta } \\ \text { SNR, } & \text { substantia nigra pars reticulata } \\ \text { SO, } & \text { supraoptic hypothalamic nucleus } \\ \text { Sol, } & \text { nucleus solitary tract } \\ \text { SOr, } & \text { hippocampal stratum oriens } \\ \text { SP, } & \text { hippocampal stratum pyramidale } \\ \text { Sp5, } & \text { nucleus spinal tract trigeminal nerve } \\ \text { SR, } & \text { hippocampal stratum radiatum } \\ \text { st, } & \text { stria terminalis } \\ \text { Str17, } & \text { striate cortex, area 17 } \\ \text { Str18, } & \text { striate cortex, area 18 } \\ \text { STh, } & \text { subthalamic nucleus } \\ \text { SuG, } & \text { superficial gray layer superior colliculus } \\ \text { SuM, } & \text { supramammillary nucleus } \\ \text { Te, } & \text { temporal (auditory) cortex } \\ \text { Tu, } & \text { olfactory tubercle } \\ \text { Tz, } & \text { nucleus trapezoid body } \\ \text { VDB, } & \text { nucleus vertical limb diagonal band } \\ \text { Ve, } & \text { vestibular nucleus } \\ \text { VI, } & \text { ventrolateral thalamic nucleus } \\ \text { VMH, } & \text { ventromedial hypothalamic nucleus } \\ \text { VP, } & \text { ventroposterior thalamic nucleus } \\ \text { VTA, } & \text { ventral tegmental area } \\ \text { ZI, } & \text { zona incerta } \\ & \end{array}$

\section{References}

Abel EL (1980) Marihuana, the first twelve thousand years. New York: Plenum.

Aigner TG (1988) Delta-9-tetrahydrocannabinol impairs visual recognition memory but not discrimination learning in rhesus monkeys. Psychopharmacology 95:507-511.

Atweh SF, Kuhar MJ (1977) Autoradiographic localization of opiate receptors in rat brain. I. Spinal cord and lower medulla. Brain Res 124:53-67.

Bach D, Raz A, Goldman R (1976) The interactions of hashish compounds with planar lipid bilayer membranes (BLM). Biochem Pharmacol 25:1241-1244.

Borison HL, Borison R, McCarthy LE (1981) Phylogenic and neurologic aspects of the vomiting process. J Clin Pharmacol 21:23s-29s.

Broadwell RD (1975) Olfactory relationships of the telencephalon and diencephalon in the rabbit. II. An autoradiographic and horseradish peroxidase study of the efferent connections of the anterior olfactory nucleus. J Comp Neurol 164:389-410.

Bylund DB (1980) Analysis of receptor binding data. In: Short course syllabus: receptor binding techniques, pp 70-99. Bethesda, MD: Society for Neuroscience.

Camphell KA, Foster TC, Hampson RE, Deadwyler SA (1986a) $\Delta^{9}$ tetrahydrocannabinol differentially affects sensory-evoked potentials in the rat dentate gyrus. J Pharmacol Exp Ther 239:936-940.

Campbell KA, Foster TC, Hampson RE, Deadwyler SA (1986b) Effects of $\Delta^{9}$-tetrahydrocannabinol on sensory-evoked discharges of granule cells in the dentate gyrus of behaving rats. J Pharmacol Exp Ther 239:941-945.

Consroe P, Martin AR, Fish BS (1982) Use of a potential rabbit model for structure-behavioral activity studies of cannabinoids. J Med Chem 25:596-599.

Conti LH, Musty RE (1984) The effects of delta-9-tetrahydrocannabinol injections to the nucleus accumbens on the locomotor activity of rats. In: The cannabinoids: chemical, pharmacologic, and therapeutic aspects (Agurell S, Dewey WL, Willette RE, eds), pp 649-655. New York: Academic.

Courchesne E, Yeung-Courchesne R, Press GA, Hesselink JR, Jernigan TL (1988) Hypoplasia of cerebellar vermal lobules VI and VII in autism. N Engl J Med 318:1349-1354.

Deadwyler SA, Heyser CJ, Michaelis RC, Hampson RE (1990) The effects of delta-9-THC on mechanisms of learning and memory. Natl Inst Drug Abuse Res Monogr Ser 97:79-95.

Devane WA, Dysarz FAI, Johnson MR, Melvin LS, Howlett AC (1988) 
Determination and characterization of a cannabinoid receptor in rat brain. Mol Pharmacol 34:605-613.

Dewey WL (1986) Cannabinoid pharmacology. Pharmacol Rev 38: $151-178$.

Drew WG, Slagel DE (1973) Selective impairment of corticosterone uptake by limbic structures of the rat. Neuropharmacology 12:909914.

Eichenbaum H, Cohen NJ (1988) Representation in the hippocampus: what do hippocampal neurons encode? Trends Neurosci 11:244-248.

Eldridge JC, Landfield PW (1990) Cannabinoid interactions with glucocorticoid receptors in rat hippocampus. Brain Res 534:135-141.

Fitton AG, Pertwee RG (1982) Changes in body temperature and oxygen consumption rate of conscious mice produced by intrahypothalamic and intracerebroventricular injections of $\Delta^{9}$-tetrahydrocannabinol. Br J Pharmacol 75:409-414.

Foy MR, Teyler TJ, Vardaris RM (1982) $\Delta^{9}$-THC and 17- $\beta$-estradiol in hippocampus. Brain Res Bull 8:341-345.

Gaoni Y, Mechoulam R (1964) Isolation, structure, and partial synthesis of an active constituent of hashish. J Am Chem Soc 86:1646.

Garrett ER, Hunt CA (1974) Physiochemical properties, solubility, and protcin binding of $\Delta^{9}$-tetrahydrocannabinol. J Pharm Sci 63 : 1056-1064.

Gilbert PE (1981) A comparison of THC, nantradol, nabilone, and morphine in the chronic spinal dog. J Clin Pharmacol 21:311S-319S.

Gilman AG (1987) G proteins: transducers of receptor-generated signals. Annu Rev Biochem 56:615-649.

Gough AL, Olley JE (1978) Catalepsy induced by intrastriatal injections of $\Delta^{9}-\mathrm{THC}$ and $11-\mathrm{OH}-\Delta^{9}-\mathrm{THC}$ in the rat. Neuropharmacology $17: 137-144$.

Green K, Kim K (1976) Mediation of ocular tetrahydrocannabinol effects by adrenergic nervous system. Exp Eye Res 23:443-448.

Green K, Bigger JF, Kim K, Bowman K (1977) Cannabinoid action on the eye as mediated through the central nervous system and local adrenergic activity. Exp Eye Res 24:189-196.

Grunfeld Y, Edcry H (1969) Psychopharmacological activity of the active constituents of hashish and some related compounds. Psychopharmacologia (Berlin) 14:200-210.

Harris LS, Dewey WL, Razdan RK (1977) Cannabis. Its chemistry, pharmacology, and toxicology. In: Handbook of experimental pharmacology (Martin WR, ed), pp 371-429. New York: Springer.

Harris LS, Carchman RA, Martin BR (1978) Evidence for the existence of specific cannabinoid binding sites. Life Sci 22:1131-1138

Herkenham M (1987) Mismatches between neurotransmitter and receptor localizations in brain: observations and implications. Neuroscience 23:1-38

Herkenham M (1988) Influence of tissue treatment on quantitative receptor autoradiography. In: Molecular neuroanatomy (van Leeuwen F, Buijs RM, Pool CW, Pach O, eds), pp 111-120. Amsterdam: Elsevier.

Herkenham M (1991) Characterization and localization of cannabinoid receptors in brain: an in vitro technique using slide-mounted tissue sections. Natl Inst Drug Abuse Res Monogr Ser, in press.

Herkenham M, Lynn AB, de Costa B, Richfield EK (1989) Neuronal localization of cannabinoid receptors in the basal ganglia. Soc Neurosci Abstr 15:905.

Herkenham M, Lynn AB, Little MD, Johnson MR, Melvin LS, de Costa BR, Rice KC (1990) Cannabinoid receptor localization in brain. Proc Natl Acad Sci USA 87:1932-1936.

Hilliard CJ, Harris RA, Bloom AS (1985) Effects of the cannabinoids on physical properties of brain membranes and phospholipid vesicles: fluorescent studies. J Pharmacol Exp Ther 232:579-588.

Hollister LE (1986) Health aspects of cannabis. Pharmacol Rev 38: $1-20$.

Hollister LE, Gillespie HK (1974) Delta-8- and delta-9-tetrahydrocannabinol. Comparison in man by oral and intravenous administration. Clin Pharmacol Ther 14:353-357.

Hollister LE, Gillespie HK, Mechoulam R, Srebnik M (1987) Human pharmacology of $1 S$ and $1 R$ enantiomers of delta-3-tetrahydrocannabinol. Psychopharmacology 92:505-507.

Howlett AC (1987) Cannabinoid inhibition of adenylate cyclase: relative activity of constituents and metabolites of marijuana. Neuropharmacology 26:507-512.

Howlett AC, Johnson MR, Melvin LS, Milne GM (1988) Nonclassical cannabinoid analgesics inhibit adenylate cyclase: development of a cannabinoid receptor model. Mol Pharmacol 33:297-302.
Howlett AC, Bidaut-Russell M, Devane WA, Melvin LS, Johnson MR Herkenham M (1990) The cannabinoid receptor: biochemical, anatomical and behavioral characterization. Trends Neurosci 13:420423.

Hubner CB, Koob GF (1990) The ventral pallidum plays a role in mediating cocaine and heroin self-administration in the rat. Brain Res 508:20-29.

Johnson MR, Melvin LS (1986) The discovery of nonclassical cannabinoid analgetics. In: Cannabinoids as therapeutic agents (Mechoulam R, ed), pp 121-145. Boca Raton, FL: CRC.

Jones RT, Benowitz N (1976) The 30-day trip-clinical studies of cannabis tolerance and dependence. In: The pharmacology of marihuana, Vol 2 (Braude MC, Szara S, eds), pp 627-642. New York: Raven.

Kalia MP (1981) Anatomical organization of central respiratory neurons. Annu Rev Physiol 43:105-120.

Kelley AE, Domesick VB, Nauta WJH (1982) The amygdalostriatal projection in the rat - an anatomical study by anterograde and retrograde tracing methods. Neuroscience 7:615-630.

Koe BK, Milne GM, Weissman A, Johnson MR, Melvin LS (1985) Enhancement of brain [ $\left.{ }^{3} \mathrm{II}\right]$ flunitrazepam binding and analgesic activity of synthetic cannabimimetics. Eur J Pharmacol 109:201-212.

Kujtan PW, Carlen PL, Kapur BM (1983) $\Delta^{9}$-Tetrahydrocannabinol and cannabidiol: dose-dependent effects on evoked potentials in the hippocampal slice. Can J Physiol Pharmacol 61:420-426.

Little PJ, Compton DR, Johnson MR, Martin BR (1988) Pharmacology and stereoselectivity of structurally novel cannabinoids in mice. J Pharmacol Exp Ther 247:1046-1051.

Liu JH, Dacus AC (1987) Central nervous system and peripheral mechanisms in ocular hypotensive effect of cannabinoids. Arch Opthalmol 150:245-248.

Loewy AD, Burton $H$ (1978) Nuclei of the solitary tract: efferent projections to the lower brain stem and spinal cord of the cat. J Comp Neurol 181:421 450 .

Manno JE, Kiplinger GF, Haine SE, Bennett IF, Forney RB (1970) Comparative effects of smoking marihuana or placebo on human motor and mental performance. Clin Pharmacol Ther 11:808-815.

Margulies JE, Hammer RP (1990) Biphasic effect of CP 55,940, a THC analog, on metabolic activity in rat brain. Soc Neurosci Abstr $16: 740$.

Margulies JE, Hammer RP (1991) THC alters cerebral metabolism in limbic and cortical regions in a biphasic, dose-dependent manner. Alc Drug Res, in press.

Martin BR (1986) Cellular effects of cannabinoids. Pharmacological Rev 38:45-74.

Martin BR, Balster RL, Razdan RK, Harris LS, Dewey WL (1981) Behavioral comparisons of the stereoisomers of tetrahydrocannabinols. Life Sci 29:565-574.

Matsuda LA, Lolait SJ, Brownstein MJ, Young AC, Bonner TI (1990) Structure of a cannabinoid receptor: functional expression of the cloned cDNA. Nature 346:561-563.

McGeorge AJ, Faull RLM (1989) The organization of the projection from the cerebral cortex to the striatum in the rat. Neuroscience 29: 503-537.

McGonigle P, Neve KA, Molinoff PB (1986) A quantitative method of analyzing the interaction of slightly selective radioligands with multiple receptor subtypes. Mol Pharmacol 30:329-337.

Mechoulam R (1986) The pharmacohistory of Cannabis sativa. In: Cannabinoids as therapeutic agents (Mechoulam $R$, ed), pp $1-19$. Boca Raton, FL: CRC.

Mechoulam R, Shani A, Edery H, Grunfeld Y (1970) Chemical basis of hashish activity. Science 169:611-612.

Mehler WR (1983) Observations on the connectivity of the parvicellular reticular formation with respect to a vomiting center. Brain Behav Evol 23:63-80.

Meinck H-M, Schonle PW, Conrad B (1989) Effect of cannabinoids on spasticity and ataxia in multiple sclerosis. J Neurol 236:120-122.

Melvin LS, Johnson MR, Harbert CA, Milne GM (1984) A cannabinoid derived prototypical analgesic. J Med Chem 27:67-71.

Miller LL, Braconnier RJ (1983) Cannabis: effects on memory and the cholinergic limbic system. Psychol Bull 93:441-456.

Millhorn DE, Eldridge FL (1986) Role of ventrolateral medulla in regulation of respiratory and cardiovascular systems. J Appl Physiol 61:1249-1263.

Moss DE, Montgomery SP, Salo AA (1984) Tetrahydrocannabinol 
effects on extrapyramidal motor behaviors in an animal model of Parkinson's disease. In: The cannabinoids: chemical, pharmacologic, and therapeutic aspects (Agurell S, Dewey WL, Willette RE, eds), pp 815-828. New York: Academic.

Nye JS, Seltzman HH, Pitt CG, Snyder SH (1985) High-affinity cannabinoid binding sites in brain membranes labeled with $\left[{ }^{3} \mathrm{H}\right]-5^{\prime}$-trimethylammonium $\Delta^{8}$-tetrahydrocannabinol. J Pharmacol Exp Ther 234:784-791.

Nye JS, Voglmaier S, Martenson RE, Snyder SH (1988) Myelin basic protein is an endogenous inhibitor of the high-affinity cannabinoid binding site. J Neurochem 50:1170-1178.

Nye JS, Snowman AM, Voglmaier S, Snyder SH (1989) High-affinity cannabinoid binding site: regulation by ions, ascorbic acid, and nucleotides. J Neurochem 52:1892-1897.

Paxinos G, Watson C (1982) The rat brain in stereotaxic coordinates. New York: Academic.

Pertwee RG (1985) Cannabis. In: Psychopharmacology 2, Pt 1: Preclinical psychopharmacology (Grahame-Smith DG, Cowan PJ, eds), pp 364-391. Amsterdam: Elsevier.

Pertwee RG (1988) The central neuropharmacology of psychotropic cannabinoids. Pharmacol Ther 36:189-261.

Pertwee RG, Greentree SG (1988) Delta-9-tetrahydrocannabinol-induced catalepsy in mice is enhanced by pretreatment with flurazepam or chlordiazepoxide. Neuropharmacology 27:485-491.

Puder M, Weidenfield J, Chowers I, Nir I, Conforti N, Siegel RA (1982) Corticotrophin and corticosterone secretion following $\Delta^{\mathrm{I}}$-tetrahydrocannabinol, in intact and in hypothalamic deafferented male rats. Exp Brain Res 46:85-88.

Reichman M, Nen W, Hokin LE (1988) $\Delta^{9}$-Tetrahydrocannabinol increases arachadonic acid levels in guinea pig cerebral cortex slices. Mol Pharmacol 34:823-828.

Rogers AW (1979) Techniques of autoradiography. New York: Elsevier.

Roth SH, Williams PJ (1979) The non-specific membrane binding properties of $\Delta^{9}$-tetrahydrocannabinol and the effects of various solubilizers. J Pharm Pharmacol 31:224-230.

Rothman RB (1986) Binding surface analysis: an intuitive yet quantitative method for the design and analysis of ligand binding studies. Alcohol Drug Res 6:309-325.

Rothman RB, Schumacher UK, Pert CB (1983) Binding of radiolabeled opiates to slide mounted sections of molded minced rat brain: a novel method for conducting radioreceptor assays. Neuropeptides $3: 493-499$

Rothman RB, Long JB, Bykov V, Jacobson AE, Rice KC, Holaday JW (1988) $\beta$-FNA binds irreversibly to the opiate receptor complex: in vivo and in vitro evidence. J Pharmacol Exp Ther 247:405-416.

Schulze GE, McMillan DE, Bailey JR, Scallet A, Ali SF, Slikker WJ, Paule MG (1988) Acute effects of $\Delta$-9-tetrahydrocannabinol in rhesus monkeys as measurcd by performance in a battery of complex operant tests. J Pharmacol Exp Ther 245:178-186.

Sweet DL, Miller NJ, Weddington W, Senay E, Sushelsky L (1981) $\Delta^{9}$-Tetrahydrocannabinol as an antiemetic for patients receiving cancer chemotherapy. A pilot study. J Clin Pharmacol 21:70S-75S.
Switzer RCI, Hill J, Heimer L (1982) The globus pallidus and its rostroventral extension into the olfactory tubercle of the rat: a cytoand chemoarchitectural study. Neuroscience 7:1891-1904.

Thompson RF, Berger TW, Madden JI (1983) Cellular processes of learning and memory in the mammalian CNS. Annu Rev Neurosci $6: 447-491$.

Turkanis S $\Lambda$, Karler R (1981a) Electrophysiological properties of the cannabinoids. J Clin Pharmacol 21:449S-463S.

Turkanis SA, Karler R (1981b) Excitatory and depressant effects of delta' ${ }^{9}$ THC and CBD on cortical evoked responses in the conscious rat. Psychopharmacologia (Berlin) 75:249-258.

Turkanis SA, Karler R (1982) Central excitatory properties of delta9-tetrahydrocannabinol and its metabolites in iron-induced epileptic rats. Neuropharmacology 21:7-13.

Turkanis SA, Karler R (1987) Different cannabinoids exhibit different electrophysiological properties. Natl Inst Drug Abuse Res Monogr Ser 79:67-81.

Vollmer RR, Cavero I, Ertel RJ, Soloman TA, Buckley JP (1974) Role of the central autonomic nervous system in the hypotension and bradycardia induced by (-)- $\Delta^{9}$-trans-tetrahydrocannabinol. J Pharm Pharmacol 26:186-192.

Weinberger DR, Kleinman JE, Luchins DJ, Bigelow LB, Wyatt RJ (1980) Cerebellar pathology in schizophrenia: a controlled postmortem study. Am J Psychiatry 137:359-361.

Weisz DJ, Gunnell DL, Teyler TJ, Vardaris RM (1982) Changes in hippocampal CA1 population spikes following administration of delta-9-THC. Brain Res Bull 8:155-162.

Wilson RS, May EL (1975) Analgesic properties of the tetrahydrocannabinols, their metabolites, and analogs. J Med Chem 18:700703.

Wilson RS, May EL, Martin BR, Dewey WL (1976) 9-Nor-9-hydroxyhexahydrocannabinols. Synthesis, some behavioral and analgesic properties, and comparison with the tetrahydrocannabinols. J Med Chem 19:1165-1167.

Wilson RS, May EL, Dewey WL (1979) Some 9-hydroxycannabinoidlike compounds. Synthesis and evaluation of analgesic and behavioral properties. J Med Chem 22:886-888.

Worley PF, Baraban JM, De Souza EB, Snyder SH (1986) Mapping second messenger systems in the brain: differential localization of adenylate cyclase and protein kinase C. Proc Natl Acad Sci USA 83: 4053-4057.

Yaksh TL (1981) The antinociceptive effects of intrathecally administered levonantradol and desacetyllevonantradol in the rat. J Clin Pharmacol 21:334S-340S.

Yoshimura H, Watanabe K, Oguri K, Fujiwara M, Ueki S (1978) Synthesis and pharmacological activity of a phosphate ester of $\Delta^{8}$ tetrahydrocannabinol. J Med Chem 21:1079-1081.

Zezula J, Cortés R, Probst A, Palacios JM (1988) Benzodiazepine receptor sitcs in the human brain: autoradiographic mapping. Ncuroscience 25:771-795. 